\title{
Intracellular Recordings from Neurobiotin-labeled Cells in Brain Slices of the Rat Medial Nucleus of the Trapezoid Body
}

\author{
Matthew I. Banks and Philip H. Smith \\ Neuroscience Training Program and Departments of Anatomy and Neurophysiology, University of Wisconsin, Madison, \\ Wisconsin 53706
}

Principal cells in the medial nucleus of the trapezoid body (MNTB) are believed to be critical components in the circuit subserving sound localization. These cells, located in the superior olivary complex, convert excitatory inputs, arriving from the contralateral cochlear nucleus by way of large somatic synapses (the calyces of Held), to inhibitory projections onto principal cells in the ipsilateral lateral superior olive (LSO). We have characterized a population of cells in the rat MNTB using intracellular recording and labeling techniques in a brain slice preparation. MNTB principal cells had spherical or ellipsoid somata that gave rise to single largediameter dendrites, which branched extensively and often extended beyond the borders of MNTB. Commonly observed axonal projection targets included LSO, the superior paraolivary nucleus, and the medial superior olive, and occasionally the lateral nucleus of the trapezoid body. The projections of individual MNTB cells showed an orderly topography that is consistent with the known tonotopic maps of the nuclei. In response to current injection, principal cells exhibited several nonlinearities, including rectification for depolarizing currents and a "sag" in the membrane potential for hyperpolarizing currents. Superthreshold depolarizing currents elicited transient firing behavior. Application of the potassium channel blocker 4-aminopyridine reduced or eliminated the rectification in the current-voltage relationships and caused depolarizing currents to elicit repetitive firing. Stimulation of afferent inputs elicited short-latency spikes, presumably driven by calyceal synaptic inputs; long-latency, presumably polysynaptic, EPSPs; and short- and long-latency IPSPs. The duration of synaptic events was strongly dependent on membrane potential, and this effect was probably due to the intrinsic membrane properties of the cell. In all cases tested, EPSPs were blocked by CNQX or DNQX, and IPSPs were blocked by strychnine. Two injected nonprincipal cells differed from principal cells in their morphologies and physiological characteristics.

The nuclei of the superior olivary complex (SOC) are thought to be involved in processing binaural information necessary for sound localization (for reviews, see Yin and Kuwada, 1984;

\footnotetext{
Received Nov. 22, 1991; revised Feb. 19, 1992; accepted Feb. 24, 1992.

We thank N. Golding, L. Haberly, R. Pearce, L. Trussell, and T. Yin for their valuable comments, I. Siggelkow, J. Eckleberry, and J. Meister for histological support, C. Dizack for illustrations, and T. Stewart for photographic help. This work was supported by NSF Grant BNS-8901993 and NIH First Grant NS26285.

Correspondence should be addressed to Matthew I. Banks, University of Wisconsin, Department of Neurophysiology, 283 Medical Sciences Building, 1300 University Avenue, Madison, WI 53706.

Copyright (C) 1992 Society for Neuroscience $0270-6474 / 92 / 122819-19 \$ 05.00 / 0$
}

Irvine, 1986). Principal cells of the medial nucleus of the trapezoid body (MNTB) have been postulated to convert excitatory inputs from the contralateral cochlear nucleus (CN; Warr, 1972; Smith et al., 1991) to inhibitory projections onto principal cells in the lateral superior olive (LSO; Glendenning et al., 1985; Spangler et al., 1985; Wenthold et al., 1987). Cells in LSO compare this contralateral inhibitory input from MNTB with ipsilateral excitatory input, a configuration believed to underlie their sensitivity to interaural level differences (Boudreau and Tsuchitani, 1968; Caird and Klinke, 1983) and perhaps to interaural timing differences (ITDs) as well (Joris and Yin, 1990; Finlayson and Caspary, 1991).

MNTB principal cells receive input from globular bushy cells (GBCs) in the contralateral CN (Warr, 1972; Tolbert et al., 1982; Glendenning et al., 1985; Friauf and Ostwald, 1988; Spirou et al., 1990; Smith et al., 1991). These afferents envelop the somata of principal cells with some of the largest synaptic terminals in the CNS, the calyces of Held (Held, 1893; Morest, 1968). The calyceal terminal is believed to provide a fast and secure relay of information from GBCs to LSO, although the responses of cells in MNTB to acoustic stimuli in vivo are not always the same as those of GBCs (Guinan et al., 1972a,b; Smith et al., 1989). Anatomical studies have also demonstrated non-calyceal innervation of MNTB cells (Lenn and Reese, 1966; Smith et al., 1989; Adams and Mugnaini, 1990; Kuwabara et al., 1991).

There have been few in vivo studies of the physiology of cells in MNTB (Guinan et al., 1972a,b; Smith et al., 1989). One in vitro study using a brain slice preparation of the mouse SOC showed that cells assumed to be in MNTB have nonlinear current-voltage $(I-V)$ relationships and fire one or a few action potentials in response to sustained depolarizing current (Wu and Kelly, 1991), responses similar to those of CN bushy cells (Oertel, 1983; Wu and Oertel, 1984; Manis and Marx, 1991). However, the cells in MNTB were not morphologically identified.

In this study, we describe the anatomical and physiological properties of single cells in MNTB of the rat using conventional microelectrodes and intracellular labeling. We sought to demonstrate these cells' major projections within the SOC, and to show that identified MNTB principal cells have membrane properties similar to those of $\mathrm{CN}$ bushy cells. In addition, we wished to determine the extent of non-calyceal synaptic input to MNTB principal cells, and to investigate the pharmacological properties of calyceal and non-calyceal inputs to these cells.

\section{Materials and Methods}

Tissue preparation. Male hooded rats (3-5 weeks old) were anesthetized with chloral hydrate $(42 \mathrm{mg} / 100 \mathrm{gm}$ body weight, i.p.) and perfused intracardially with $50 \mathrm{cc}$ of room-temperature saline in which $\mathrm{NaCl}$ had 
Table 1. Anatomical abbreviations

$\begin{array}{ll}\text { CN } & \text { Cochlear nucleus } \\ \text { DMPO } & \text { Dorsomedial periolivary nucleus } \\ \text { GBC } & \text { Globular bushy cell } \\ \text { IC } & \text { Inferior colliculus } \\ \text { LNTB } & \text { Lateral nucleus of the trapezoid body } \\ \text { LSO } & \text { Lateral superior olive } \\ \text { MNIB } & \text { Medial nucleus of the trapezoid body } \\ \text { MSO } & \text { Medial superior olive } \\ \text { SOC } & \text { Superior olivary complex } \\ \text { SPN } & \text { Superior paraolivary nucleus } \\ \text { TB } & \text { Trapezoid body } \\ \text { VMPO } & \text { Ventromedial periolivary nucleus } \\ \text { VNTB } & \text { Ventral nucleus of the trapezoid body }\end{array}$

been replaced by sucrose (S-saline; composition: $240 \mathrm{~mm}$ sucrose, $5 \mathrm{~mm}$ $\mathrm{KCl}, 1.2 \mathrm{mM} \mathrm{KH}_{2} \mathrm{PO}_{4}, 2.4 \mathrm{~mm} \mathrm{CaCl}, 1.3 \mathrm{mM} \mathrm{MgSO}_{4}, 26 \mathrm{~mm} \mathrm{NaHCO}_{3}$, $10 \mathrm{~mm}$ glucose, $\mathrm{pH}$ adjusted with $\mathrm{HCl}$ to 7.4 at room temperature and subsequent to saturation with $95 \% \mathrm{O}_{2}, 5 \% \mathrm{CO}_{2}$; Aghajanian and Rasmussen, 1989). The animals were immediately decapitated, and the portion of the brainstem directly ventral to the cerebellum was rapidly removed and placed in room-temperature S-saline. The tissue was trimmed, blotted dry, and glued to a plastic tray with cyanoacrylate glue. A block made of egg albumin was also glued to the tray to support the tissue on the sides and from behind. The tray was filled with S-saline, and $400 \mu \mathrm{m}$ coronal slices were cut with a vibratome, using the seventh nerve as a landmark for choosing slices (Paxinos and Watson, 1986). The time elapsed between the start of the perfusion procedure and the completion of slicing was typically less than $8 \mathrm{~min}$.

Appropriate slices were transferred to a holding apparatus, where they were allowed to recover in S-saline at room temperature for about 20 min, followed by normal saline (composition same as S-saline, except $120 \mathrm{~mm} \mathrm{NaCl}$ instead of $240 \mathrm{~mm}$ sucrose, $\mathrm{pH}$ adjusted with $\mathrm{HCl}$ to 7.4 at $33.5^{\circ} \mathrm{C}$ and subsequent to saturation with $95 \% \mathrm{O}_{2}, 5 \% \mathrm{CO}_{2}$ ) that was gradually warmed to $\sim 28^{\circ} \mathrm{C}$. After another $30 \mathrm{~min}$, one slice, chosen based on its general appearance and the presence of the SOC, was transferred to a two-sided perfusion brain slice chamber (modified from Nicoll and Alger, 1981) and perfused continuously $(2 \mathrm{ml} / \mathrm{min})$ with $33.5^{\circ} \mathrm{C}$ saline saturated with $95 \% \mathrm{O}_{2}, 5 \% \mathrm{CO}_{2}$. Recordings were usually begun about $1 \mathrm{hr}$ after transferring the slice to the chamber.

Intracellular recording. Intracellular recordings were obtained using conventional glass microelectrodes pulled on a Flaming-Brown P87 micropipette puller and connected to a Neurodata IR-283 intracellular recording amplifier. Microelectrodes were filled with a $2 \%$ solution of neurobiotin (Vector Labs) in $2 \mathrm{M} \mathrm{K}$-acetate buffered to $\mathrm{pH} 7.4$ with acetic acid, and had resistances of $80-120 \mathrm{M} \Omega$.

Afferent fibers were stimulated at rates of $3-6 \mathrm{~Hz}$ with concentric bipolar stimulating electrodes that provided a highly focal stimulation (outer contact diameter, $150 \mu \mathrm{m}$; inner contact diameter, $25 \mu \mathrm{m}$; Rhodes Medical Instruments MCE-100). One electrode was placed in the trapezoid body (TB) at the midline and another in the ipsilateral TB ventrolateral to LSO. Stimulation was controlled via a Grass stimulator (S8800) and stimulus isolation unit (SIU5).

Cells were impaled by applying large $(>10 \mathrm{~V})$, short depolarizing pulses while advancing the microelectrode in $\sim 2-4 \mu \mathrm{m}$ steps through the slice. Upon impalement, cells were stabilized by applying hyperpolarizing bias current, which was gradually removed before recording data. Cells were judged to be healthy if they had resting potentials between approximately -50 and $-75 \mathrm{mV}$ and action potential amplitudes of greater than $\sim 40 \mathrm{mV}$ (peak to trough). Stable recordings often lasted $>1 \mathrm{hr}$ and as long as $6.5 \mathrm{hr}$. Intracellular stimuli consisted of polarizing current pulses or sinusoidal currents, generated using a World Precision Instruments pulse generator (A310) or a Wavetek frequency generator (model 185). Current and voltage records were digitized and sampled at $14.9 \mathrm{kHz}$ (Tecmar Labmaster A/D; Compaq DeskPro 386 SX computer) and stored on optical disk (IBM 3363) for subsequent data analysis. Cells were injected with neurobiotin using depolarizing current pulses ( $200 \mathrm{msec}$ duration, $1-3 \mathrm{nA}, 2.5 \mathrm{~Hz}$ for $\sim 4 \mathrm{~min}$ ).

Gross injections. Gross injections of neurobiotin were performed using pressure injections (General Valve Picospritzer II) of $2 \%$ neurobiotin in $2 \mathrm{M}$ polassium acetate, as for intracellular injections. Glass electrodes with tip sizes of $\sim 20 \mu \mathrm{m}$ were advanced through the tissue, stopping every $50 \mu \mathrm{m}$ to inject neurobiotin with pulses $200 \mathrm{msec}$ long at $15 \mathrm{psi}$. The slice was then processed as for intracellular experiments.

Tissue processing. After injection, the slice was left in the recording chamber for $>0.5 \mathrm{hr}$, then removed and fixed [4\% paraformaldehyde in $0.1 \mathrm{M}$ sodium phosphate $\left(\mathrm{PO}_{4}\right)$ buffer, $\left.\mathrm{pH} 7.4\right]$ for $>12 \mathrm{hr}$. Slices were rinsed in $\mathrm{PO}_{4}$ buffer and cryoprotected by passing them through a series of glycerol-sucrose solutions of increasing concentration ( $0 \%$ glycerol, $5 \%$ sucrose; $5 \%, 10 \% ; 10 \%, 15 \% ; 10 \%, 20 \%$; all in $0.1 \mathrm{M} \mathrm{PO}_{4}$ buffer). Frozen sections $(60 \mu \mathrm{m})$ were cut using a microtome, the cryoprotection procedure was reversed, and the sections were rinsed in $0.1 \mathrm{M} \mathrm{PO}_{4}$ buffer. Sections were incubated overnight in the secondary antibody of an avidin-biotin-HRP complex (ABC Kit, Vector Labs) and then rinsed in $\mathrm{PO}_{4}$ buffer, and the HRP was reacted using the diaminobenzidinenickel/cobalt intensification method (Adams, 1981). Finally, the sections were mounted, dehydrated, and counterstained with cresyl violet.

Pharmacological agents. 6,7-Dinitroquinoxaline-2,3-dione [DNQX; Research Biochemicals Inc. (RBI)], 6-cyano-7-nitroquinoxaline-2,3dione (CNQX; RBI), strychnine (Sigma), (-)-bicuculline methiodide (Sigma), and 4-aminopyridine (4-AP; Sigma) were bath applied by adding the substances to normal saline at appropriate concentrations.

Data analysis. These data are based on recordings from 47 cells localized to MNTB subsequent to injection with neurobiotin. Most of these cells (45 of 47) were identified as principal cells, based on comparisons of their morphology to previously published descriptions in other animals (Morest, 1968; Ollo and Schwartz, 1979).

Stained cells were drawn using a camera lucida connected to either a Zeiss or Nikon microscope with a $100 \times$ objective. Low-power $(10 \times$ or $20 \times$ ) drawings of the nuclei of the SOC were drawn using either conventional camera lucida or a computerized neuron tracing system (Eutectics). "Areas of termination" (e.g., in the SPN, Fig. 4) were determined by drawing a smooth curve by eye around the swellings representing the perimeter of the termination pattern in the nucleus.

A nucleus was considered to be a projection target only if terminal arbors were present, and not if an axon merely passed through the nucleus. In all cases presented here, axons were well filled. In the rare case that a cell's axon could not be followed due to a lack of reaction product, that cell was not included in the anatomical results. The approach that we have taken in describing target areas of MNTB principal cells was to decide whether it seemed likely that a particular cell was bypassing a nucleus, or whether such a projection was still possible. We based these decisions on the following argument: the axons of MNTB principal cells always progressed from medial to lateral in the slice, typically innervating the medial superior olive (MSO) and/or the superior paraolivary nucleus (SPN) and then LSO. Thus, if a cell's axon reached the LSO without innervating, for example, MSO (see Fig. 3), and if no major cut branches were apparent, then that cell was said to bypass MSO. When we report that " $x$ out of $y$ " cells projected to a nucleus, that means $x$ cells projected to the nucleus and $(y-x)$ cells bypassed the nucleus.

In order to illustrate a topographic organization of the projection to MSO, the MNTB was normalized along its mediolateral dimensions and divided into lateral, middle, and medial thirds. This normalization was performed on drawings of sections containing the somata of cells that either projected to or bypassed MSO.

Transient and steady-state $I-V$ curves were constructed by averaging portions of the voltage response to polarizing currents (transient, 20 msec window centered on the peak voltage deflection; steady-state, from $t=150$ to $190 \mathrm{msec}$, for $200 \mathrm{msec}$ pulses). To ensure that electrode nonlinearities did not contaminate the $I-V$ data, electrodes were tested subsequent to exiting a cell by passing polarizing currents in the bath. Voltage responses corresponding to current amplitudes that resulted in significant electrode polarization were discarded. The input resistances for hyperpolarizing and depolarizing currents $\left(R_{I N(h)}, R_{I N(d)}\right)$ were computed from the slope of a line fitted to the hyperpolarizing and depolarizing portions of the $I-V$ curve.

Synaptic events were characterized by three parameters: latency, amplitude, and half-width. The latency was measured from the beginning of the stimulus artifact to the first noticeable deflection from the baseline membrane potential. The half-width is a measure of the duration of the synaptic potential, and is defined as the width of the synaptic potential at half-maximal amplitude. Unless otherwise indicated, data are presented as mean \pm standard deviation. For a summary of the anatomical abbreviations used in this article, see Table 1. 

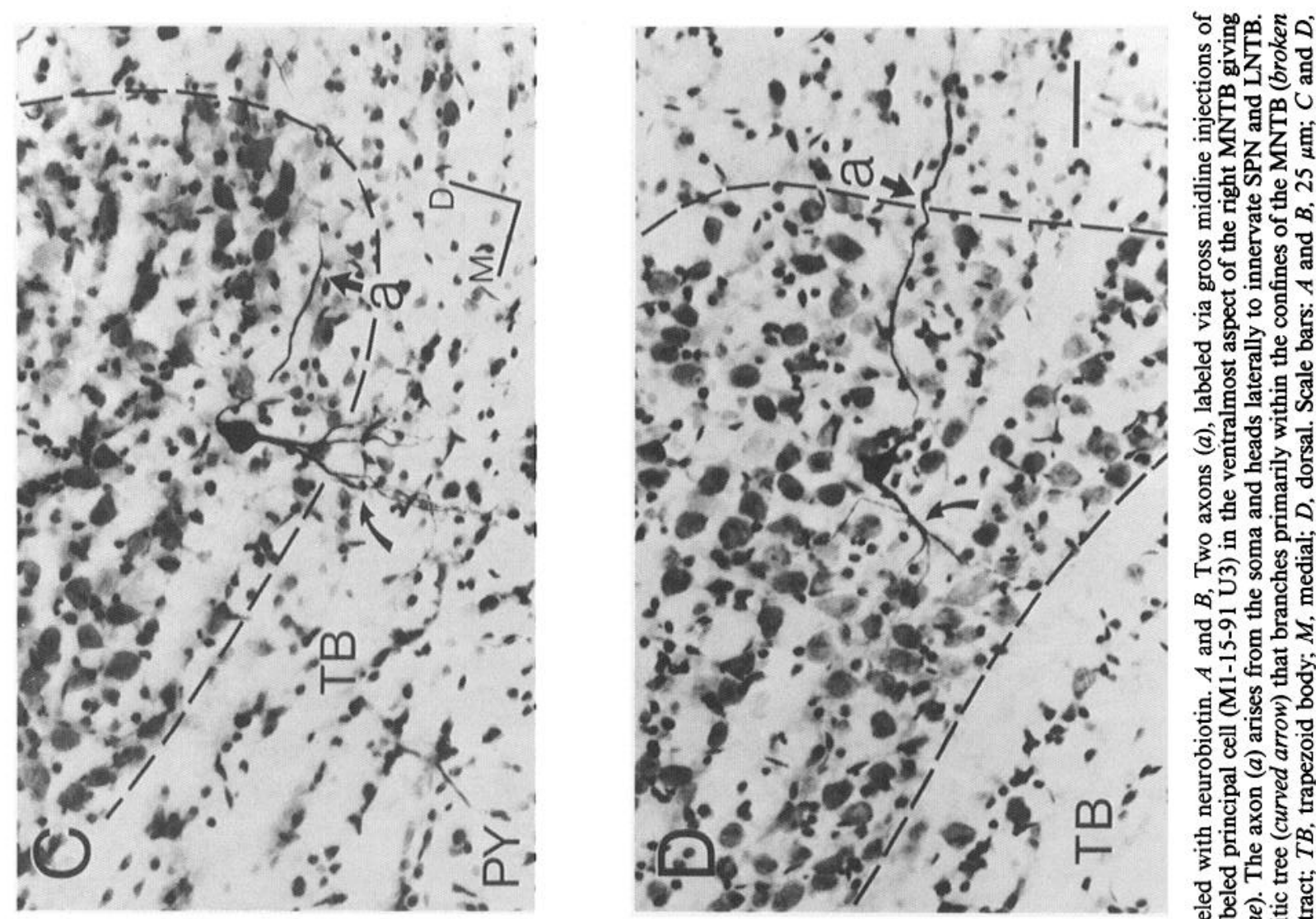

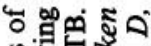

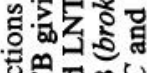

ชี้ำำ

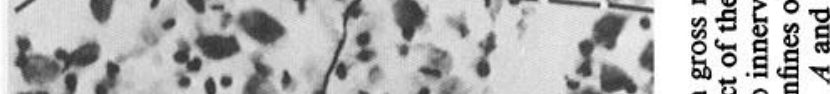

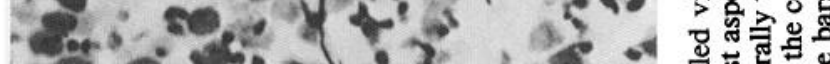

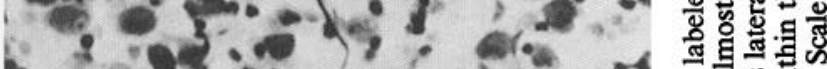

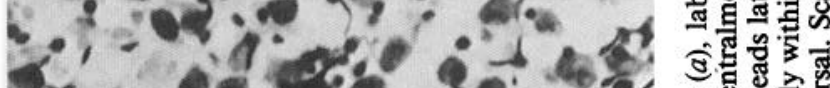

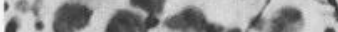

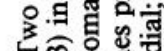

s.

ใิ่

运定定

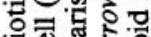

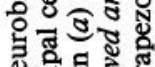

प.

겸요 要通 केष 西要
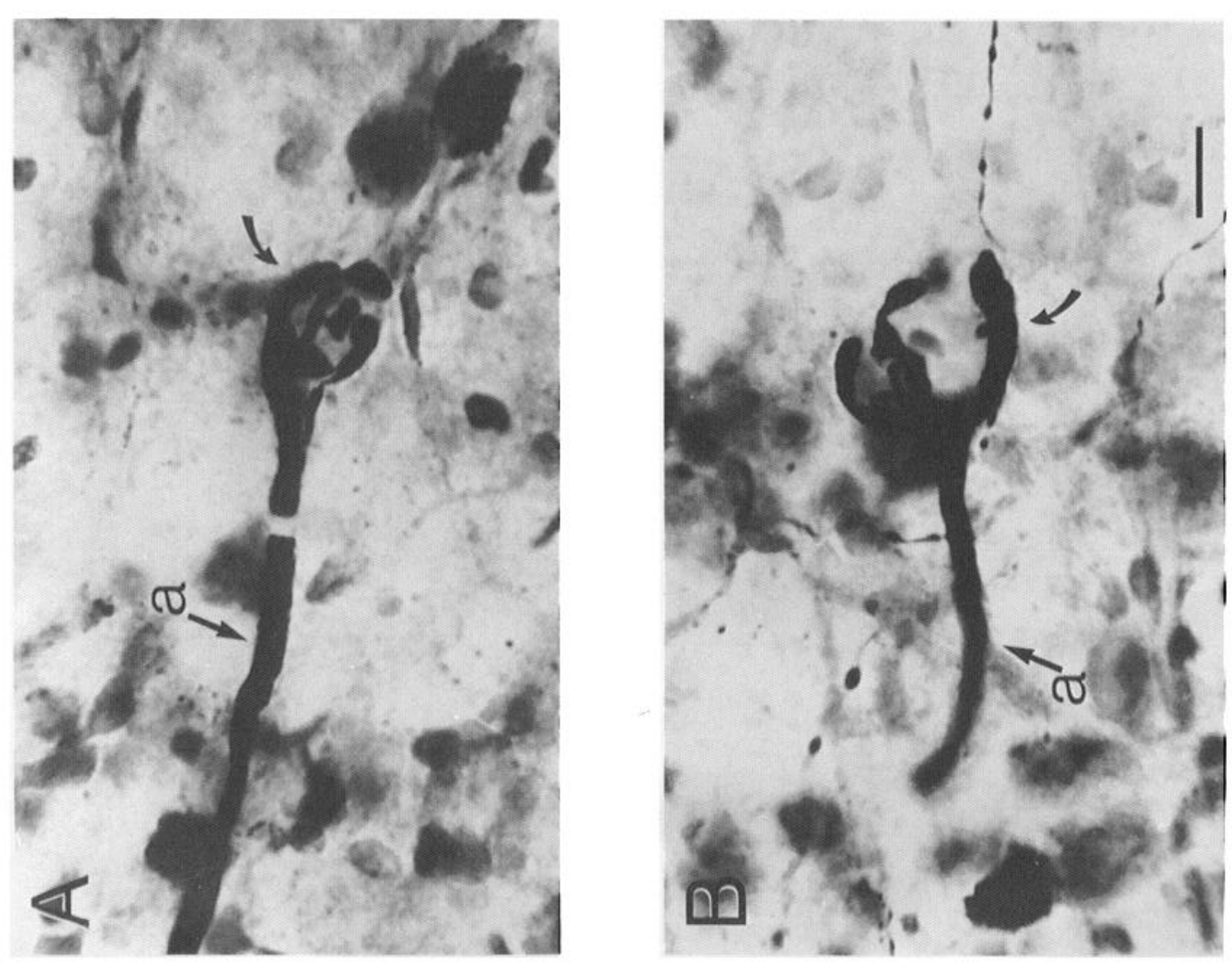

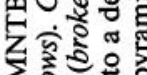

प 5 色.

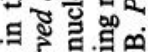

嗮焉的

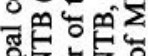

嗮些之。

동영

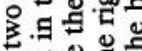

물웅

뭉

平然

पे

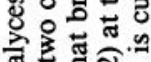

สี

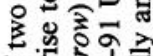

它 5 ते

ตับ

要的经

唈记

घ형

융을

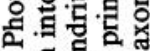

-

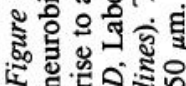




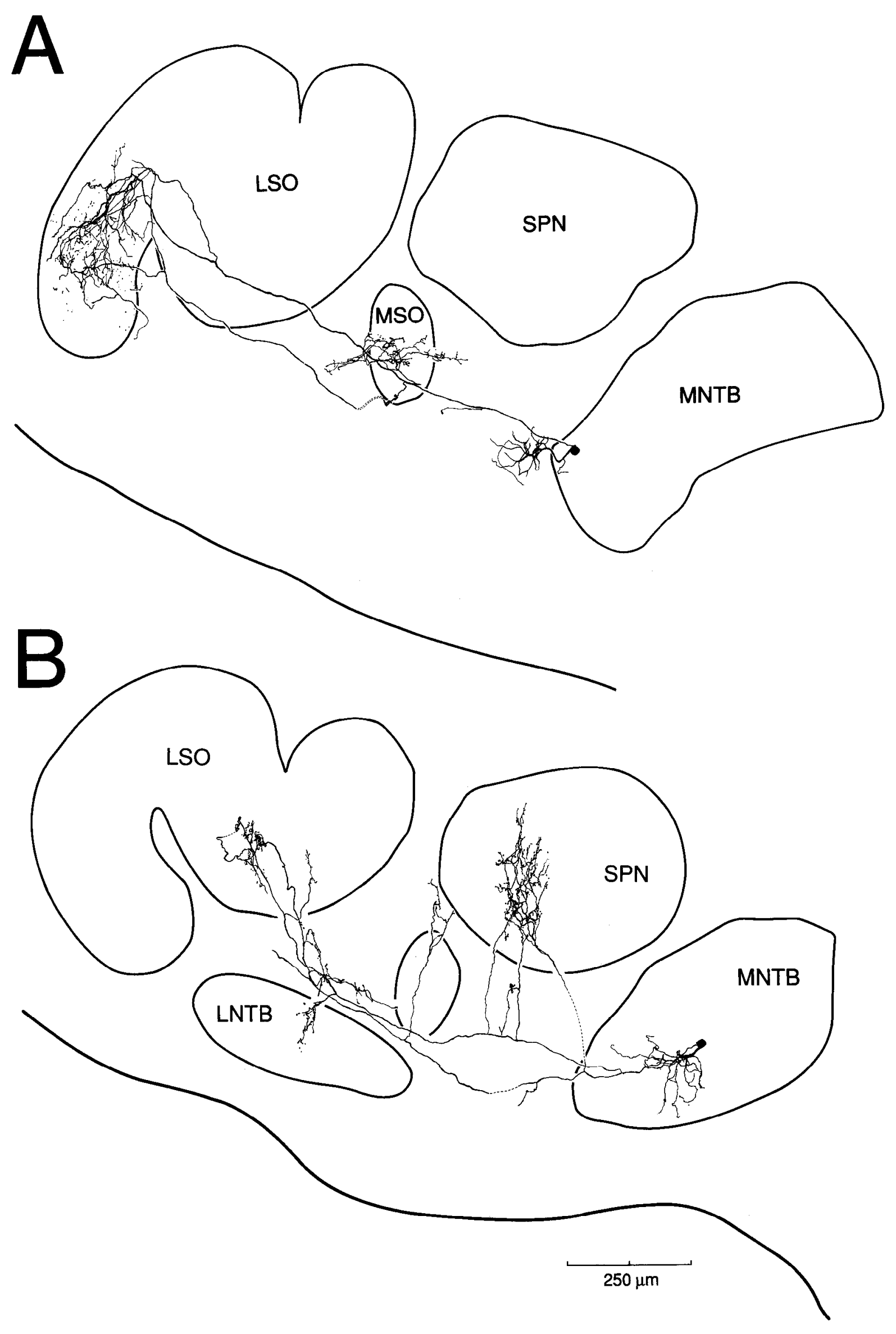




\section{Results}

\section{Gross injections}

We made gross injections of neurobiotin into the TB in order to confirm the possibility of stimulating calyceal inputs at the midline in our slices. Photomicrographs of two labeled calyces in MNTB appear in Figure $1, A$ and $B$. These calyces have morphologies similar to those described in the cat (Morest, 1973; Smith et al., 1991). Gross injections into the TB close to the midline labeled numerous calyces in the contralateral (and ipsilateral) MNTB, indicating that activation of these inputs by midline stimulation was possible.

\section{Anatomy of $M N T B$ principal cells}

Somatic and dendritic morphology. MNTB principal cells typically had spherical or ellipsoidal somata $(22.4 \pm 3.01 \mu \mathrm{m} \times$ $15.8 \pm 2.42 \mu \mathrm{m} ; n=45$ cells), with a single, large-diameter, aspinous primary dendrite extending from the soma and branching into several smaller-diameter, aspinous dendrites. Photomicrographs of two injected cells in MNTB are illustrated in Figure $1, C$ and $D$. MNTB cells often had dendritic trees that extended beyond the somatic borders of MNTB into the path of TB fibers (Fig. 1C).

Axonal projections-general comments. The three target nuclei most often observed were LSO (9 of 9), SPN (21 of 25), and MSO (12 of 20). Occasionally, projections also went to the lateral nucleus of the trapezoid body (LNTB) (3 of 10), and in one case a collateral terminated in MNTB, in the region of the cell body.

In all cases, axons emanated directly from the cell body (Fig. $1 C, D)$, and headed dorsally, laterally, or ventrolaterally before exiting MNTB. The courses of these axons tended to fall into one of two categories: cells located in the lateral and middle thirds of MNTB typically sent their axons laterally or ventrolaterally, running through (Fig. $2 A$ ) or ventral to (Fig. $2 B$ ) MSO, and sometimes coursing with the fibers of the TB. These cells often sent off thick collateral branches in the vicinity of MSO that ran dorsally to innervate SPN (Fig. $2 B$ ). Cells located in the medial third of MNTB typically sent their axons dorsally and laterally, running through (and giving off collaterals in) SPN en route to targets in LSO (Fig. $3 A, B$ ). Because no axons progressed far enough past LSO before being cut off in the slice, it was impossible to observe projections to the nuclei of the lateral lemniscus.

Projection to LSO. We injected nine cells that had terminal fields in LSO, three each in the lateral, middle, and medial limbs. The MNTB and LSO of the cat are tonotopically organized, with the medial extent of MNTB and the medial limb of LSO representing high best frequencies (BFs), and the lateral MNTB and lateral limb of LSO devoted to low BFs (Tsuchitani and Boudreau, 1966; Guinan et al., 1972b). Although a similar arrangement has yet to be demonstrated in the rat, the projection patterns of MNTB cells that we injected are consistent with this scheme. Cells located in the lateral portion of MNTB projected to the lateral limb of LSO (Fig. $2 A$ ), cells in the central portion of MNTB projected to the middle limb of LSO (Fig. $2 B$ ), and cells located in the medial portion of MNTB projected to the medial limb of LSO (Fig. 3).

The projections of cells to LSO, especially near the dorsal hilus, were at times highly restricted along the expected tonotopic axis of LSO (e.g., Fig. $3 A$ ), forming a discreet band running perpendicular to the tonotopic axis. In all cases, projections to LSO coursed hundreds of microns rostrocaudally, often extending through the entire thickness of the slice.

Projection to SPN. SPN was a commonly observed projection target of our cell population ( 21 of 25 cells) and was innervated in a topographic fashion. Cells located in the lateral portion of MNTB projected to the lateral aspect of SPN (not shown), while cells in the central portion of MNTB projected to central SPN (Fig. $2 B$ ) and cells in medial MNTB projected to medial SPN (Fig. $3 A, B$ ). The terminal fields were oriented dorsoventrally and restricted mediolaterally. This projection pattern suggests a tonotopic inhibitory projection from MNTB to SPN. The projections of five cells to SPN are summarized in Figure 4. The right column shows the location of the cell body of the injected MNTB cells, and each cell's area of termination in SPN is illustrated in the left column. A clear, orderly projection pattern is apparent: as the cells progress from medial to lateral in MNTB (top to bottom in Fig. 4), their areas of termination also progress from medial to lateral in SPN. In addition, two cells located at the same mediolateral position in MNTB, but at very different dorsoventral positions, sent projections to SPN that almost entirely overlapped in both the mediolateral and dorsoventral dimensions (not shown). None of the 21 cells projecting to SPN violated this projection scheme, although on occasion there were minor projections to other regions of SPN (Fig. 3B). These results suggest a tonotopic axis in SPN with approximately the same orientation as that in MNTB.

Projection to MSO. Projections to MSO were seen in 12 of 20 principal cells and were much more common among cells located in the lateral, low-BF portion of MNTB. The terminal fields of the cells illustrated in Figures $2 A$ and 5 showed collaterals and swellings that were oriented perpendicular to the long axis in MSO and appeared to extend both medially and laterally beyond the borders of MSO. Although no topographic organization of the innervation pattern within MSO was apparent (compare Figs. 2A,5), there were topographic restrictions on which cells sent collaterals to MSO: out of the 20 cells that either projected to or bypassed MSO, 8 of 8 cells located in the lateral third of MNTB projected to MSO, while 4 of 9 cells in the middle third and 0 of 3 cells in the medial third of MNTB projected to MSO.

Projections to LNTB and MNTB. Occasionally (3 of 10), principal cells projected to LNTB. These cells showed areas of termination in LNTB that were restricted along the mediolateral axis of the nucleus (Fig. $2 B$ ). On only one occasion did a cell give off a collateral that terminated within or near the borders of MNTB (Fig. 5). The terminal arbors of this collateral were in the same section as the cell body.

\footnotetext{
Figure 2. Camera lucida drawings of two MNTB principal cells, in the coronal plane (all subsequent drawings are in the coronal plane), and their axonal projection patterns. $A$, Principal cell (M11-13-90 U3) in the lateral extreme of the left MNTB giving rise to an axon that heads laterally to innervate the MSO and the LSO. $B$, Principal cell (M11-7-90 U4) in the middle third of the MNTB giving rise to an axon that heads laterally to innervate the middle of the SPN, the middle limb of the LSO, and the LNTB. Thick lines ventral to the SOC in $A$ and $B$ represent the ventral edge of the brainstem.
} 


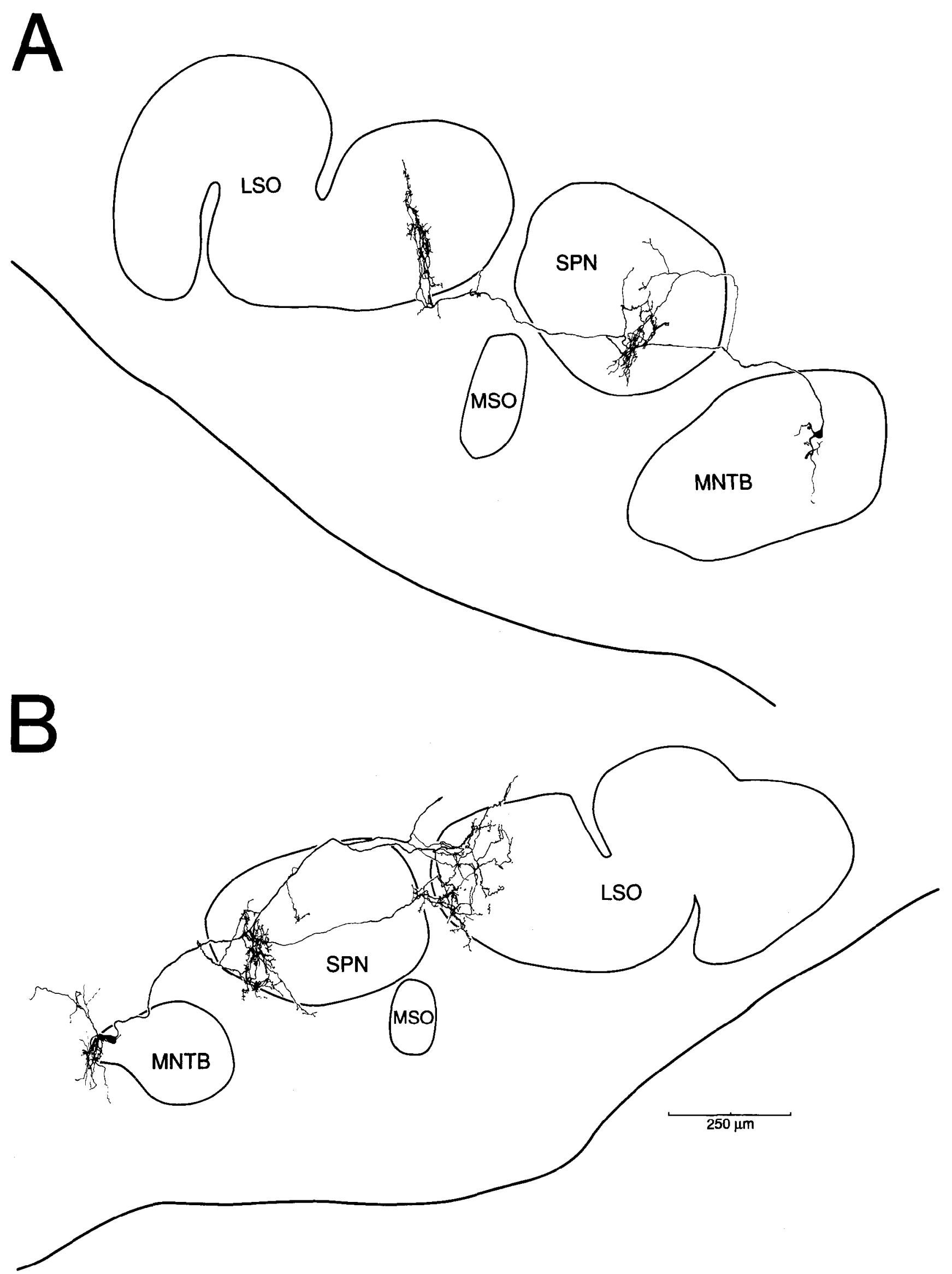

Figure 3. Camera lucida drawings of two MNTB principal cells, and their axonal projection patterns. $A$, Principal cell (M2-19-91 U2) in the medial third of the left MNTB giving rise to an axon that heads dorsally and laterally to innervate the medial aspect of the SPN and the medial limb of the LSO. B. Principal cell (M4-9-91 U2) in the medial extreme of the right MNTB giving rise to an axon with projections to the medial extent of the SPN and the medial limb of the LSO. 
Physiology of MNTB principal cells

General comments. These physiological data arc bascd on recordings from the same population of cells as the anatomical data presented above. These cells had resting potentials of 62.4 $\pm 5.35 \mathrm{mV}$ and action potential amplitudes of $51.3 \pm 10.2 \mathrm{mV}$. Except as noted, the data presented are typical of this population of cells in MNTB.

Current-voltage relationships. Current-voltage data for MNTB principal cells exhibited several nonlinearities, apparently due to the activation of voltage-dependent conductances. For example, in response to large hyperpolarizing currents, MNTB cells typically exhibited a "sag" in the membrane potential; that is, the steady-state voltage deflection was less than the peak, transient deflection (Fig. 6A,C). The transient responses to hyperpolarizing current (Fig. $6 B, D$, solid triangles) were approximately linear, with these two cells showing slopes of $65 \mathrm{M} \Omega$ (Fig. $6 B$ ) and $64 \mathrm{M} \Omega$ (Fig. $6 \mathrm{D}$ ). The steady-state responses to hypcrpolarizing current typically deviated from linearity for large currents (Fig. $6 B, D$, open triangles), with a drop in input resistance for high current levels.

Another nonlinearity in the responses of MNTB cells to current injection was the marked rectification exhibited in their $I-$ $V$ relationships. For the two cells illustrated in Figure $6, R_{\mathrm{IN}}$ dropped to $23 \mathrm{M} \Omega$ and $6.7 \mathrm{M} \Omega$, respectively, in response to depolarizing current. In order to quantify this rectification for our population of cells, we calculated the steady-state $R_{\mathrm{IN}}$ for hyperpolarizing and depolarizing current in each cell for which $I-V$ data were obtained ( $n=34$ cells). The average ratio of $R_{\mathrm{IN}(a)}$ : $R_{\mathrm{IN}(h)}$ was $0.28 \pm 0.23$, and in all but one cell, $R_{\mathrm{IN}(h)}>\mathrm{R}_{\mathrm{IN}(d)}$. A further nonlinearity exhibited during current injection was a decrease in the membrane time constant at the offset of the response to hyperpolarizing current pulses, as compared to the onset of the response (Fig. $6 A, C$ ).

The firing propertics of principal cells in response to current injection were highly dependent on the nature of the depolarizing stimulus. In response to a steady depolarizing current, MNTB principal cells fired only a single action potential at the stimulus onset (Fig. 7A), regardless of the stimulus amplitude. The single action potential had an amplitude that was graded with the stimulus amplitude (not shown). Although these cells responded transiently to sustained depolarizing currents, they were able to follow sinusoidal inputs at high firing rates. This is illustrated in Figure 7, $B$ and $C$, which shows the responses to sinusoidal current stimuli $(750 \mathrm{~Hz})$, at two different amplitudes, for the same cell as in Figure $7 A$. Just above threshold, the cell fired a few action potentials during the stimulus (arrow, Fig. 7B). At higher stimulus intensities (Fig. 7C), the cell fired on every other cycle of the stimulus without fail, corresponding to a firing rate of 375 spikes/sec.

Responses in 4-AP. The phenomena described above-nonlinear $I-V$ relationships and transient responses to sustained stimuli-are also observed in the responses of $\mathrm{CN}$ bushy cells to current injection (Oertel, 1983; Wu and Oertel, 1984; Manis and Marx, 1991) and have been postulated to be due to a 4-APsensitive, voltage-dependent potassium conductance that is observed in these cells (Manis and Marx, 1991). In order to determine whether the same conductance is present in MNTB principal cells, we applied 4-AP to the bath and observed the changes in response to current injection.

Application of 4-8 $\mathrm{mm}$ 4-AP resulted in dramatic changes in the membrane properties of MNTB cells $(n=6)$. In all six cases,
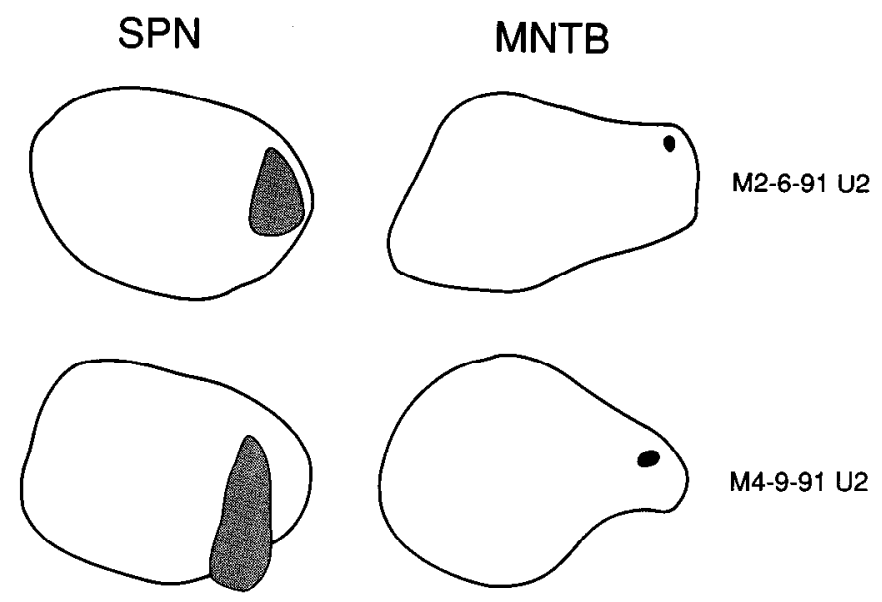

M4-9-91 U2
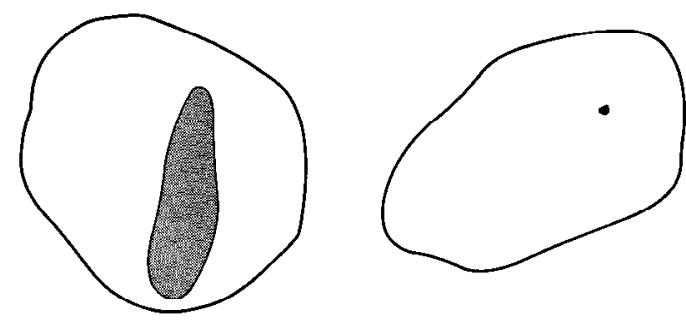

M2-19-91 U2
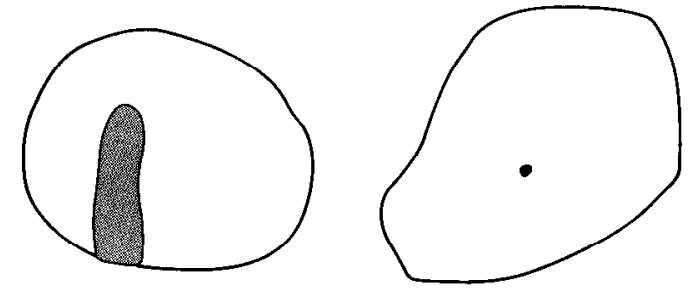

M11-7-90 U4

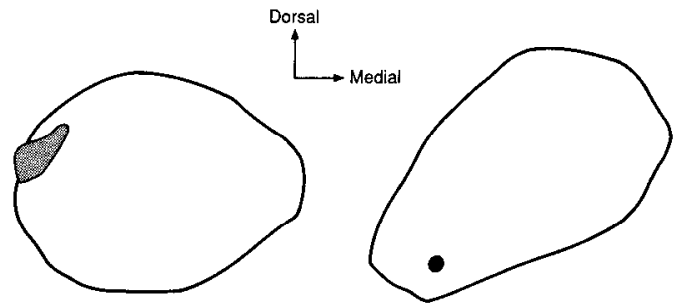

M3-2-90 U3

Figure 4. Summary of the projections of five MNTB principal cells to the SPN. Right column indicates the position of the cell body within an outline of the MNTB in the section containing the cell body. Left column indicates "areas of termination" (shaded) in an outline of the SPN (drawn from the section containing the majority of the terminal arbor) for the cells in the right column. The mediolateral dimensions of the nuclei are normalized for ease of comparison, and drawings are reflected onto the left brainstem when necessary. Method for determining "areas of termination" is discussed in Materials and Methods. Letters and numbers to the right are unit identification numbers.

4-AP caused an increase in $R_{\mathrm{IN}(d)}$ and depolarizations of about 5-10 mV. In four of six cases, depolarizing current pulses in the presence of 4-AP elicited repetitive firing. The data for one of these cells are illustrated in Figure $8 A-D$. In normal saline, this cell exhibited the typical responses to depolarizing and hyperpolarizing currents (Fig. $8 A, D$, solid triangles). When $4 \mathrm{~mm}$ 4-AP was added to the bath, depolarizing current injection elicited a train of action potentials (Fig. $8 B$ ) and a linear $I-V$ relationship for subthreshold stimuli, except for large hyperpolarizing currents (Fig. 8D, solid circles). The train of action potentials was more transient at higher depolarizations (not shown), possibly due to cumulative sodium inactivation, an 
Figure 5. Camera lucida drawing of a principal cell in the left MNTB (M920-90 U4). The dendritic tree (curved arrow) lies primarily outside the borders of the MNTB. The axon ( $a$ ) gives off a local collateral (straight arrow) and then heads laterally to innervate the MSO. Bulge at the termination of the main axon near the lateral border of the MSO is a constriction at the cut end of the axon at the top of the slice.

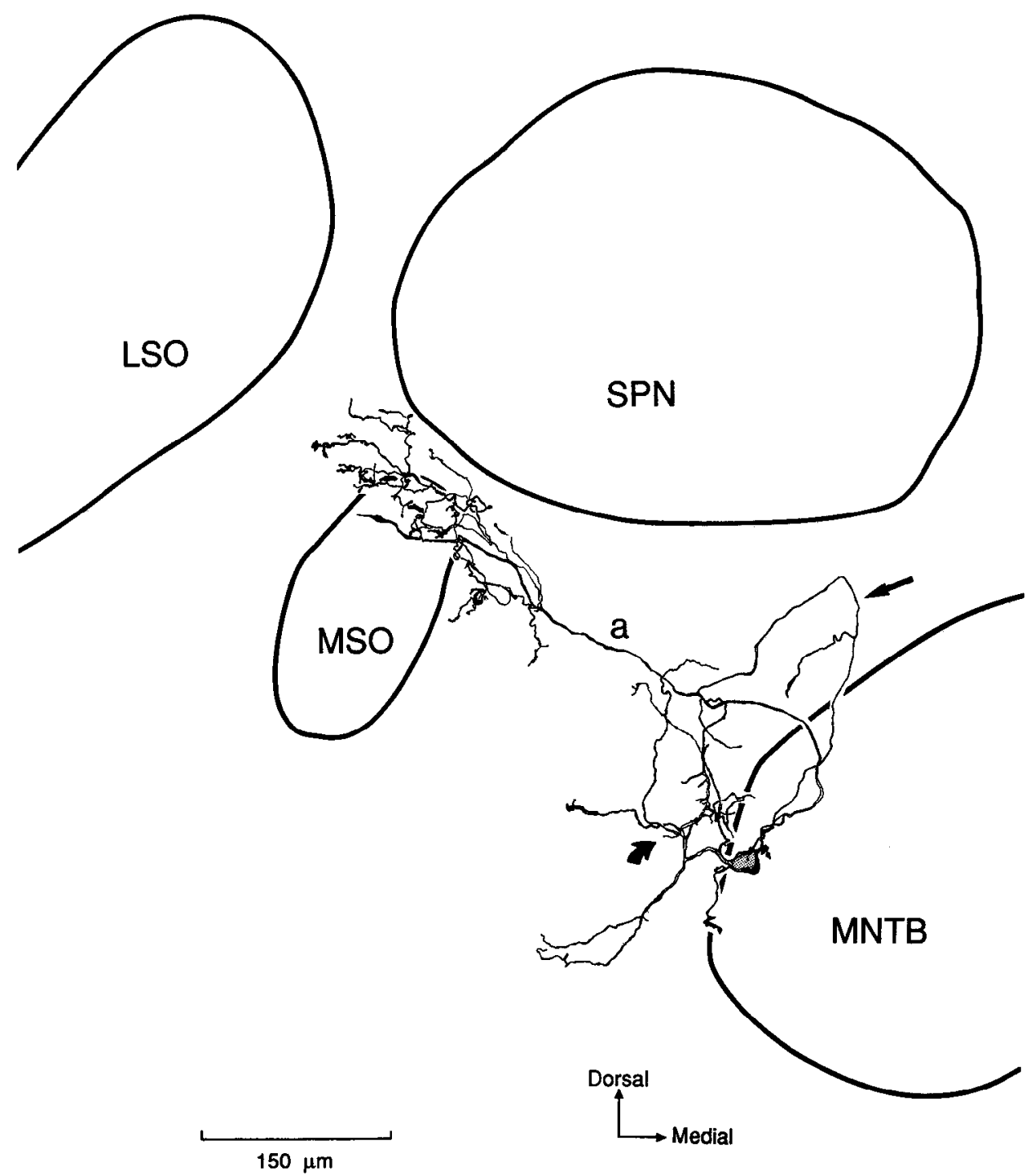

incomplete or voltage-dependent blockade of the 4-AP-sensitive conductance, or the activation of a high-threshold delayedrectifier potassium conductance. Over- and undershoots were unmasked following hyperpolarizing and depolarizing currents (arrowheads, Fig. 8B). When the cell was returned to normal saline, the effects of 4-AP were largely reversed within $20 \mathrm{~min}$ (Fig. $8 C, D$, open triangles). The values for $R_{\mathrm{IN}(\alpha)}$ and $R_{\mathrm{IN}(h)}$ in normal saline were, respectively, $6.6 \mathrm{M} \Omega$ and $27 \mathrm{M} \Omega$; in 4-AP, $38 \mathrm{M} \Omega$ and $38 \mathrm{M} \Omega$; and upon recovery, $10 \mathrm{M} \Omega$ and $35 \mathrm{M} \Omega$. The precise timing of the repetitive spikes elicited in 4-AP is illustrated for a different cell in Figure $8 E$, which shows nine superimposed responses to small depolarizing current pulses.

Synaptic responses-calyceal input. Stimulation of the TB at the midline often elicited short-latency action potentials, which occurred as all-or-nothing events as shock strength was gradually increased (Fig. 9A). Of the 41 cells in which synaptic potentials were observed, 19 responded with these short-latency events, with an average latency of $0.72 \pm 0.13 \mathrm{msec}$. An underlying synaptic event could not typically be observed, even when the membrane was hyperpolarized by $>20 \mathrm{mV}$ (Fig. 9B). The duration of this short-latency event was strongly dependent on membrane potential, with the duration longer when the cell was hyperpolarized than when it was depolarized (Fig. 9B).
We have investigated the pharmacology of this short-latency event by applying the non-NMDA excitatory amino acid (EAA) antagonist CNQX (Honore et al., 1988). Bath application of CNQX resulted in a dose-dependent blockade of the synapatic potential (Fig. 9C). In normal saline, stimulation of the TB at the midline elicited a short-latency, all-or-nothing action potential that obscured the underlying synaptic potential (Fig. $9 \mathrm{C}$, top trace). Low concentrations of CNQX $(<10 \mu \mathrm{M})$ partially blocked the calyceal EPSP, causing it to become subthreshold (Fig. 9C, second trace). At higher concentrations of CNQX, the blockade was nearly complete, although a residual component typically remained (Fig. $9 \mathrm{C}$, third and fourth traces). The effects of CNQX were usually reversed within $10 \mathrm{~min}$ (Fig. $9 C$, bottom trace). We will refer to this synaptic event as the calyceal EPSP based on its short latency and its size. In seven of seven cells, the calyceal EPSP was blocked by CNQX, with five of these cells held long enough to reverse the effect.

As illustrated in Figure $9 B$, the duration of the calyceal event was strongly dependent on the level of membrane polarization. This is also illustrated in Figure $10 \mathrm{~A}$, which shows the response of a different cell to the same stimulus paradigm, but here the baseline voltage in each trace is set at the value of the membrane potential just before the stimulus artifact. The time course of 

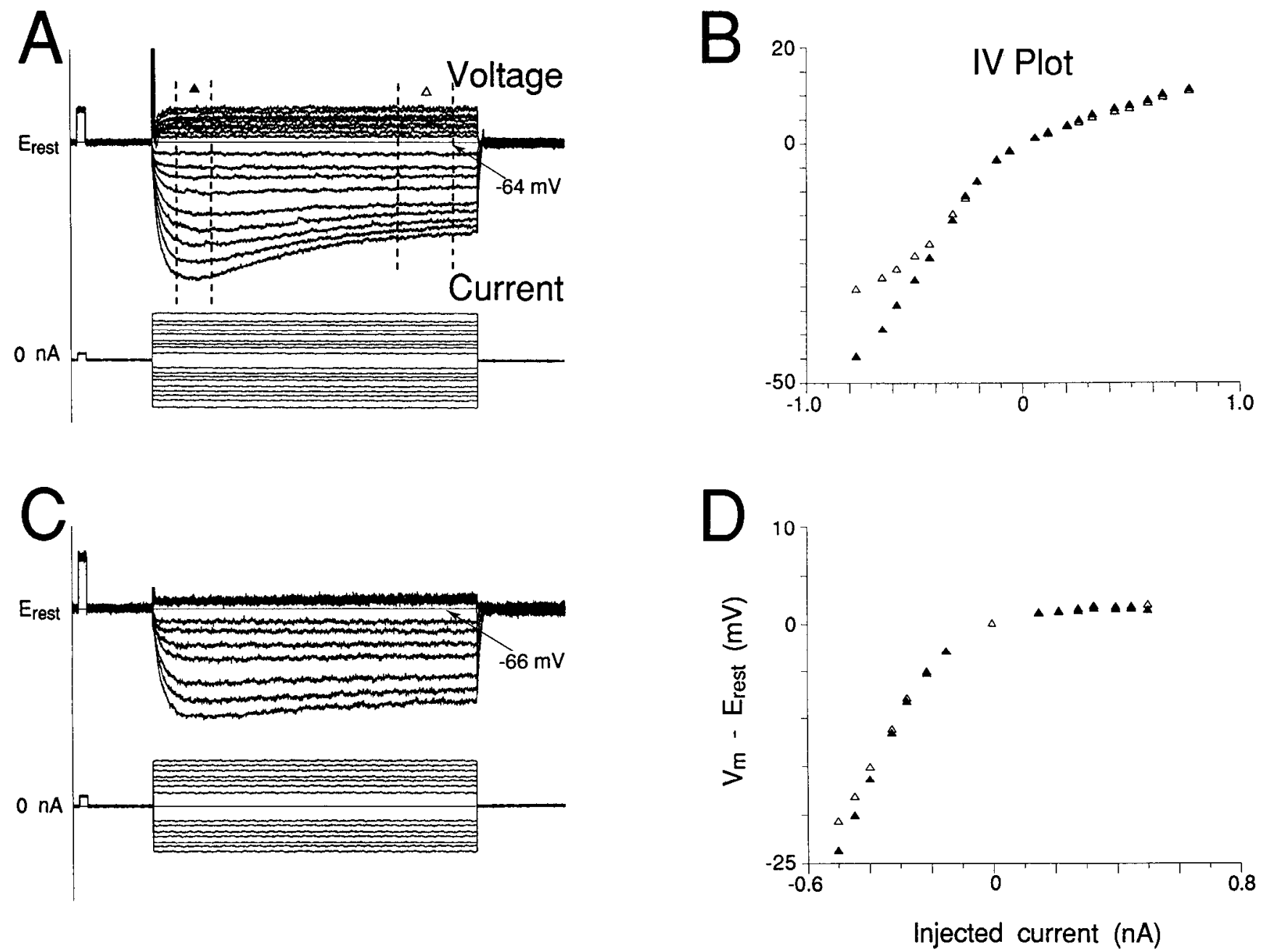

Figure 6. Membrane potential (Voltage) in response to polarizing current pulses (Current; $A, C$ ), and $I-V$ curves derived from these responses $(B, D)$, for two MNTB principal cells ( $A$ and $B$ from M7-2-91 U1, $C$ and $D$ from M2-6-91 U1). Current pulse duration is 200 msec. Calibration pulses at the onset of the traces in $A$ and $C$ are $10 \mathrm{mV}$ and $0.1 \mathrm{nA}$ in amplitude and $5 \mathrm{msec}$ in duration. Resting potential $\left(E_{\text {ress }}\right)$ is indicated to the right of the voltage responses. Broken lines through the voltage traces in $A$ delineate the windows where "transient" and "steady-state" I-V curves were derived. $I-V$ curves were constructed as described in Materials and Methods. Voltage is plotted as deflection from resting potential. Solid triangles, transient responses, averaged over $t=70-90 \mathrm{msec}$, where stimulus onset is at $50 \mathrm{msec}$; open triangles, steady-state responses, averaged over $t=210-240 \mathrm{msec}$. Action potentials in $A$ are attenuated.

the underlying EPSP, elicited under partial blockade with CNQX, showed a similar voltage dependence (Fig. 10B). Two possible explanations for this dependence on membrane potential are that (1) the calyceal EPSP was followed by a later IPSP whose reversal potential was near the resting potential (e.g., $\mathrm{a} \mathrm{Cl}^{-}$IPSP), or (2) the EPSP was terminated by a voltage-dependent conductance partially activated near rest. In the latter case, depolarization would further activate the conductance, causing a decrease in the time constant of the cell and in the duration of the synaptic potential, while hyperpolarization would deactivate the conductance, causing an increase in the duration of the event. The conductance responsible for modulating the duration of the EPSP could be the same 4-AP-sensitive conductance postulated to be responsible for the nonlinear $I-V$ and transient firing behavior observed in these cells. To distinguish between these two possibilities, we elicited calyceal spikes in the presence of a mixture of antagonists to glycine and $\mathrm{GABA}_{\mathrm{A}}$ receptors $(1 \mu \mathrm{M}$ strychnine $+50 \mu \mathrm{M}$ bicuculline), which mediate most $\mathrm{Cl}^{-}$IPSPs in the CNS (Fig. 10C,D). These antagonists had no effect on the voltage dependence of the synaptic potential decay $(n=3)$, implying that the intrinsic membrane properties of the cell may be responsible.

Synaptic responses - non-calyceal events. In addition to the calyceal EPSP, IPSPs and long-latency EPSPs were also observed. In fact, long-latency EPSPs in response to midline stimulation were the most commonly observed synaptic event in our population of MNTB cells ( 25 of 41 cells in which synaptic events were elicited). These long-latency events were often graded with shock strength, driving action potentials at the highest stimulus levels (Fig. 11A). In some cells, both calyceal events and long-latency events were observed, but this was not common ( 5 of 41 cells). The average minimum latency, maximum amplitude, and half-width for these long-latency EPSPs were $2.7 \pm 0.83 \mathrm{msec}, 7.7 \pm 2.8 \mathrm{mV}$, and $1.3 \pm 0.42 \mathrm{msec}$, respectively. Ipsilateral TB stimulation rarely elicited long-latency EPSPs ( 2 of 41 cells).

IPSPs in response to midline TB stimulation were observed in four cells, while in two other cells, stimulation of the ipsilateral TB near the seventh nerve elicited IPSPs. The IPSPs elicited from the midline were often (three of four) accompanied 

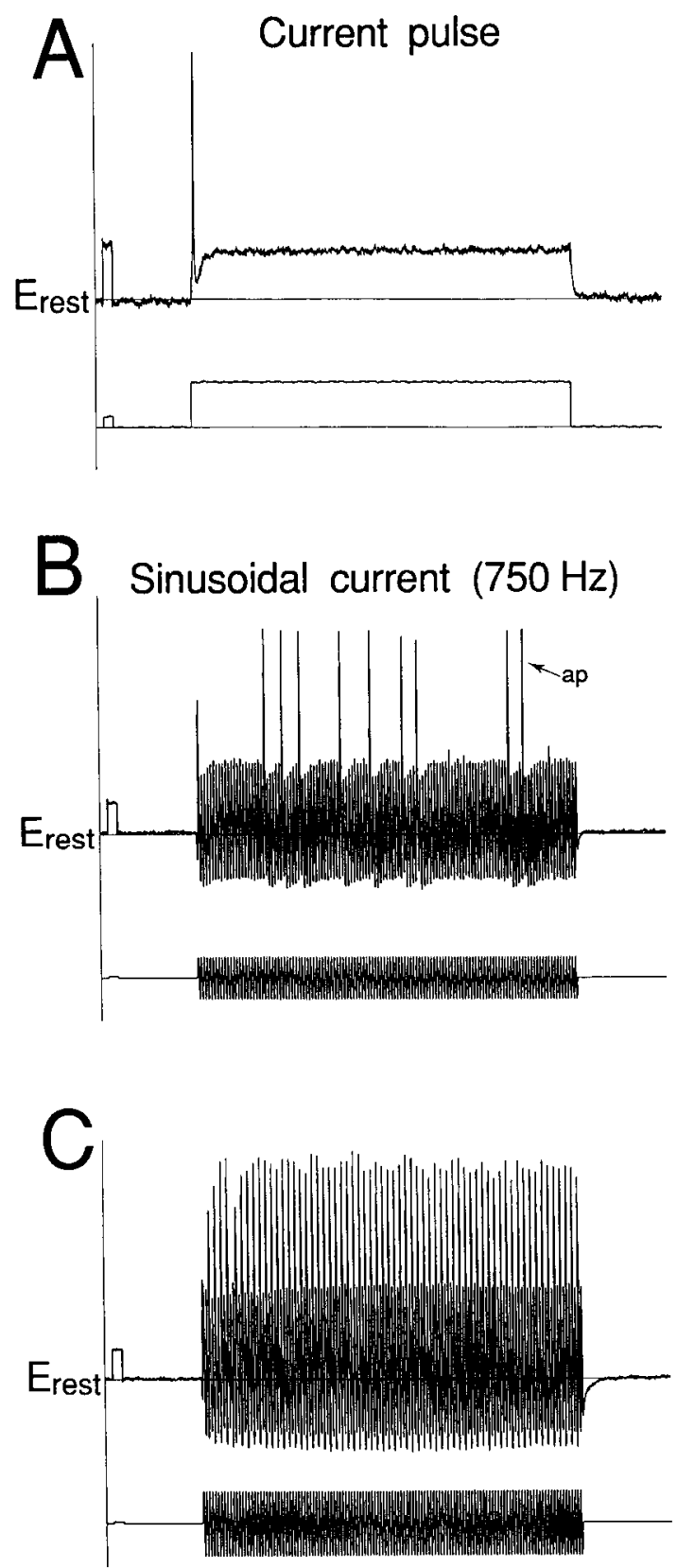

Figure 7. MNTB principal cell (M11-28-90 U1) responses to square and sinusoidal current pulses. $A$, Response (top trace) to a $200 \mathrm{msec}$ suprathreshold depolarizing square pulse (bottom trace). $B$, Barely suprathreshold response of the same cell (top trace) to a $200 \mathrm{msec}$ sinusoidal, $750 \mathrm{~Hz}$ current pulse (bottom trace). $C$, Same as $B$ but using a large-amplitude sinusoidal current. $E_{\text {rest }}=-58 \mathrm{mV}$. $a p$, action potential Calibration pulses; voltage, $10 \mathrm{mV}, 5 \mathrm{msec}$; current, $0.1 \mathrm{nA}, 5 \mathrm{msec}$.

by non-calyceal EPSPs. The latency for these midline inhibitory events varied from $0.70 \mathrm{msec}$ to $2.3 \mathrm{msec}$, and in two cells the IPSPs had latencies $<1 \mathrm{msec}$, implying that these events were monosynaptic. The IPSPs reversed at a potential very close to resting potential (Fig. $11 B$ ), indicating that they were $\mathrm{Cl}^{-}$IPSPs.

We have also investigated the pharmacology of these longlatency synaptic events. Application of strychnine, a glycine receptor antagonist, completely blocked the IPSPs observed in three cells (Fig. 11C). In all three cases the effect was irreversible after $1 \mathrm{hr}$ in normal saline, although the cells still had normal resting potentials and input resistances, and still fired action potentials. Long-latency EPSPs were blocked by application of the non-NMDA EAA antagonists DNQX or CNQX (nine of nine cells, with five of these cells held long enough to reverse the effect).

Figure 12 illustrates the blockade of both a non-calyceal EPSP and an IPSP in a single cell. Stimulation of the midline elicited an early IPSP (latency, $0.7 \mathrm{msec}$ ) followed by an EPSP (latency, $3.4 \mathrm{msec}$; Fig. $12 \mathrm{~A}$, bottom trace), which could elicit an action potential (Fig. $12 A$, top trace). Application of $22 \mu \mathrm{M}$ DNQX reversibly blocked the EPSP (Fig. 12B,C), leaving the IPSP intact, while application of $2.2 \mu \mathrm{M}$ strychnine blocked the IPSP, revealing the full EPSP (Fig. 12D).

\section{Non-principal cells: anatomy and physiology}

Two of the 47 cells had significantly different morphology and we have characterized them as non-principal cells. One cell was located in the lateral third of MNTB (Fig. 13A), while the other was located just outside the lateral border of MNTB (Fig. 13B). Both cells had bipolar somata, with their dendritic trees emanating from the poles of their cell bodies. One cell (Fig. 13A) sent its axon dorsolaterally, innervating SPN and a region just outside the medial limb of LSO. The second cell (Fig. 13B) sent its axon ventrolaterally, innervating what was presumably LNTB, although this nucleus was not distinct in this particular slice.

In addition, the non-principal cells had correspondingly different physiological characteristics. The responses of these two cells to current injection were very similar, and the data for one of these cells are shown in Figure $14 A-C$. In response to depolarizing current, both cells fired sustained trains of action potentials (Fig. 14A). The action potentials had "double undershoots," that is, afterhyperpolarizations described by two phases, one fast and one slow. The response to hyperpolarizing current (Fig. 14B) showed only a slight sag in the membrane potential, and the $I-V$ relationship (Fig. 14C) for this cell was more linear than was typical for MNTB principal cells, although there are only two points on the curve corresponding to subthreshold depolarizing currents.

Stimulation of the TB at the midline failed to produce a calyceal spike in either cell. One cell responded to midline stimulation with what appeared to be an early IPSP (latency, 1.0 msec), followed by an EPSP and perhaps a later IPSP (Fig. 14D). This cell also responded to stimulation of the ipsilateral TB near the seventh nerve with a pure IPSP (latency, $0.9 \mathrm{msec}$ ) that reversed about $10 \mathrm{mV}$ negative to $E_{\text {rest }}$ (Fig. $14 D$ ). The other non-principal cell responded to midline stimulation with a graded EPSP (latency, $1.1 \mathrm{msec}$ ) that at high shock strengths could drive an action potential (Fig. 14F). Stimulation of the ipsilateral TB elicited no response (not shown).

\section{Discussion}

Anatomy

Principal cell morphology. The morphology of single MNTB cells has been described previously in the cat (Morest, 1968), the bat and gerbil (Kuwabara and Zook, 1991), the mouse (Ollo and Schwartz, 1979; Kuwabara and Zook, 1991), and to a lesser extent in the rat (Casey and Feldman, 1982) and guinea pig (Schofield and Cant, 1991). Unlike the cells we have injected in the rat, MNTB principal cells in the cat typically have between two and four short, thin, tufted dendrites (Morest, 1968). Cells in other species are more similar to those of the rat, with each 

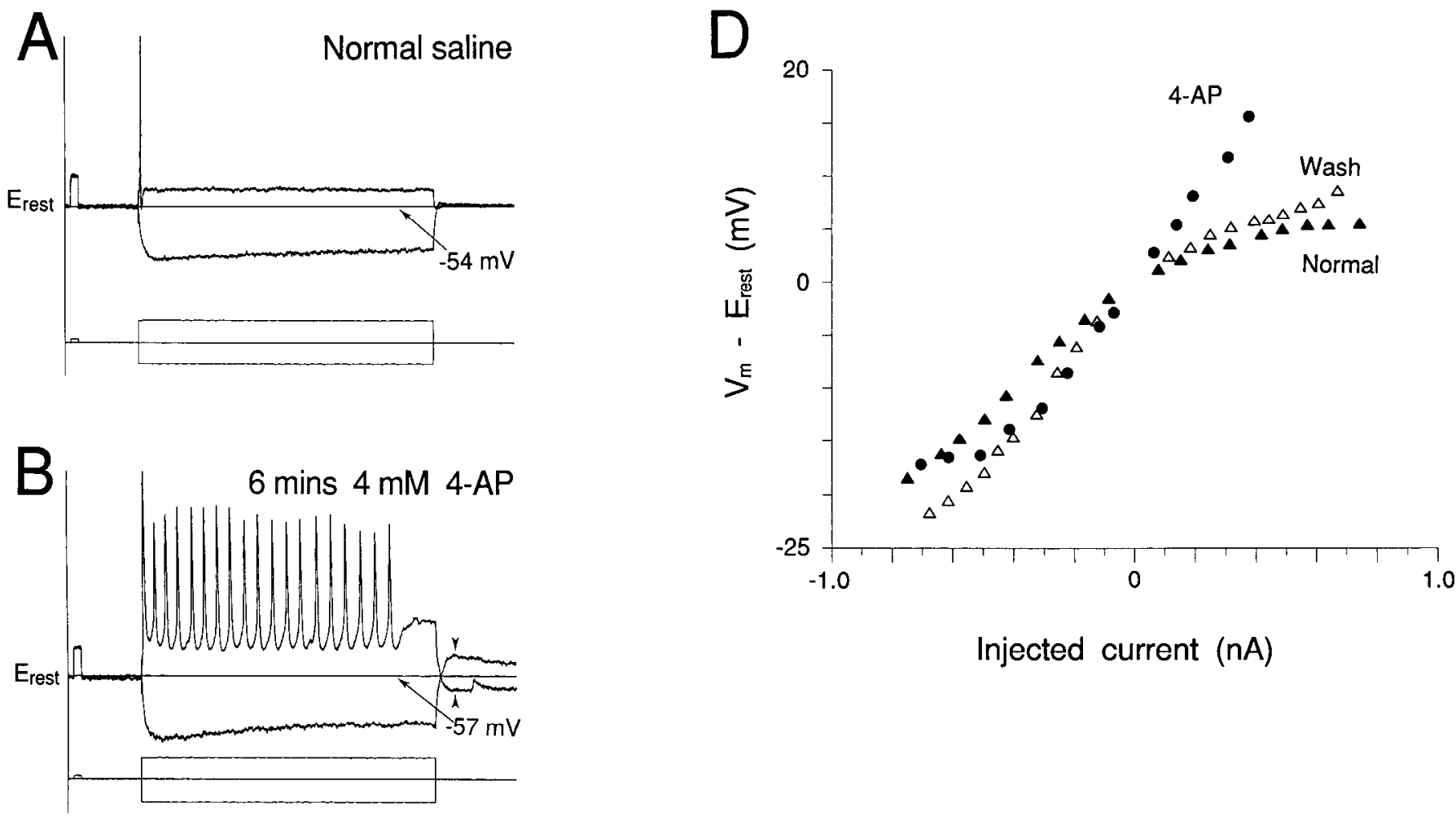

Injected current (nA)
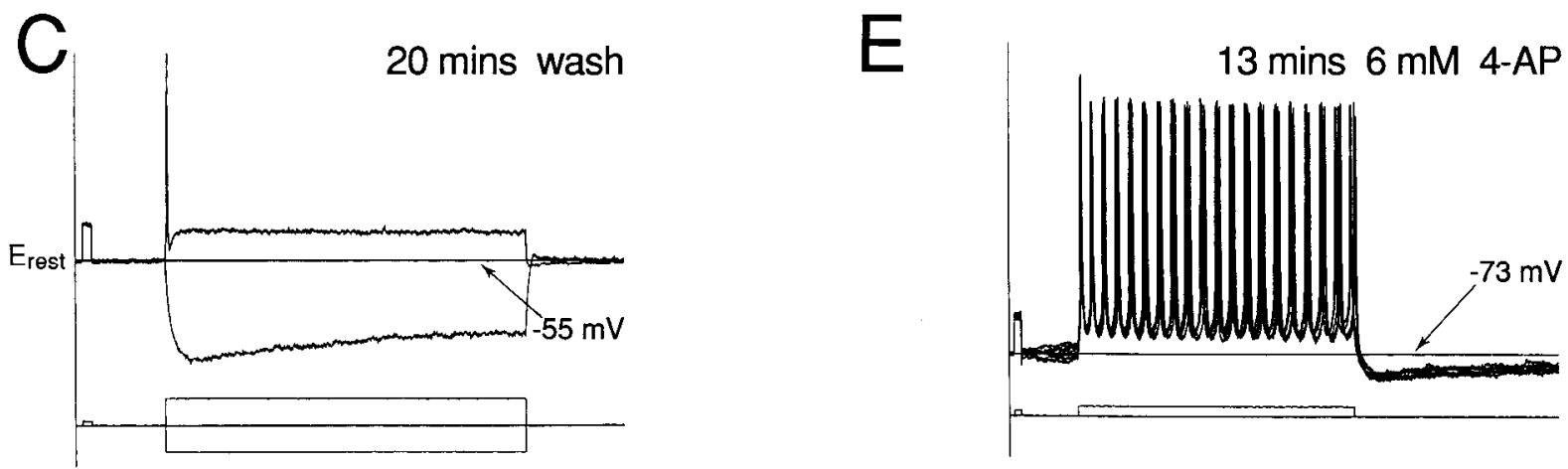

Figure 8 . Change in response properties of MNTB principal cells during bath application of 4-AP. A, Responses (top traces) of a cell (M5-23-91 U2) to $200 \mathrm{msec}$ polarizing current pulses (bottom traces) in normal saline. $B$, Responses of the same cell to the same amplitude current pulses seen in $A$, after $6 \mathrm{~min}$ in $4 \mathrm{~mm}$ 4-AP. Arrowheads indicate overshoots seen at stimulus offset in 4-AP. $C$, Responses of the same cell to current pulses of the same amplitude as seen in $A$ and $B, 20 \mathrm{~min}$ after returning to normal saline. Baseline membrane potential is indicated to the right of the voltage traces. In $A$ and $C$ this represents the resting potential. In $B$, some hyperpolarizing bias current was required to maintain this DC level. $D, I-V$ curves computed for the steady-state responses of the same cell in normal saline (solid triangles), 4-AP (solid circles), and 20 min after returning to normal saline (Wash, open triangles). $E$, Response of another cell (10-1-91 U1) to 6 mM 4-AP. Traces are superimposed responses to nine depolarizing current pulses of identical amplitude after $13 \mathrm{~min}$ in 4-AP. This cell was held at a slightly hyperpolarized level relative to resting potential in normal saline $\left(E_{\text {rest }}=-66 \mathrm{mV}\right)$ to minimize spontaneous spikes being generated in 4-AP by an increase in spontaneous synaptic events. Calibration pulses: voltage, $10 \mathrm{mV}, 5 \mathrm{msec}$; current, $0.1 \mathrm{nA}, 5 \mathrm{msec}$.

cell having one or two large primary dendritic stalks (Ollo and Schwartz, 1979; Kuwabara and Zook, 1991). MNTB cells in other species have dendritic spines (Morest, 1968; Kuwabara and Zook, 1991), which we did not observe in our cell population.

The dendritic trees of many of our principal cells extended beyond the borders of MNTB and into the path of the TB, similar to MNTB cells in other rodents and bats (Kuwabara and Zook, 1991). Since principal cells may receive non-calyceal inputs on their dendritic trees, it is possible that these non-calyceal inputs do not always enter MNTB, synapsing instead on the dendrites extending out of MNTB. One consequence of this is that studies investigating inputs to MNTB, for example, anterograde gross injection studies, may miss some of the noncalyceal inputs to MNTB.

Projections of principal cells. Because our experiments were performed on slices, the axonal processes of the injected cells were often cut off during the slicing procedure. Typically, these cells retained only portions of their axonal fields. Statements concerning the projections of these cells as determined in the slice must be treated cautiously in that projections that were not observed cannot be excluded. However, given the large size 


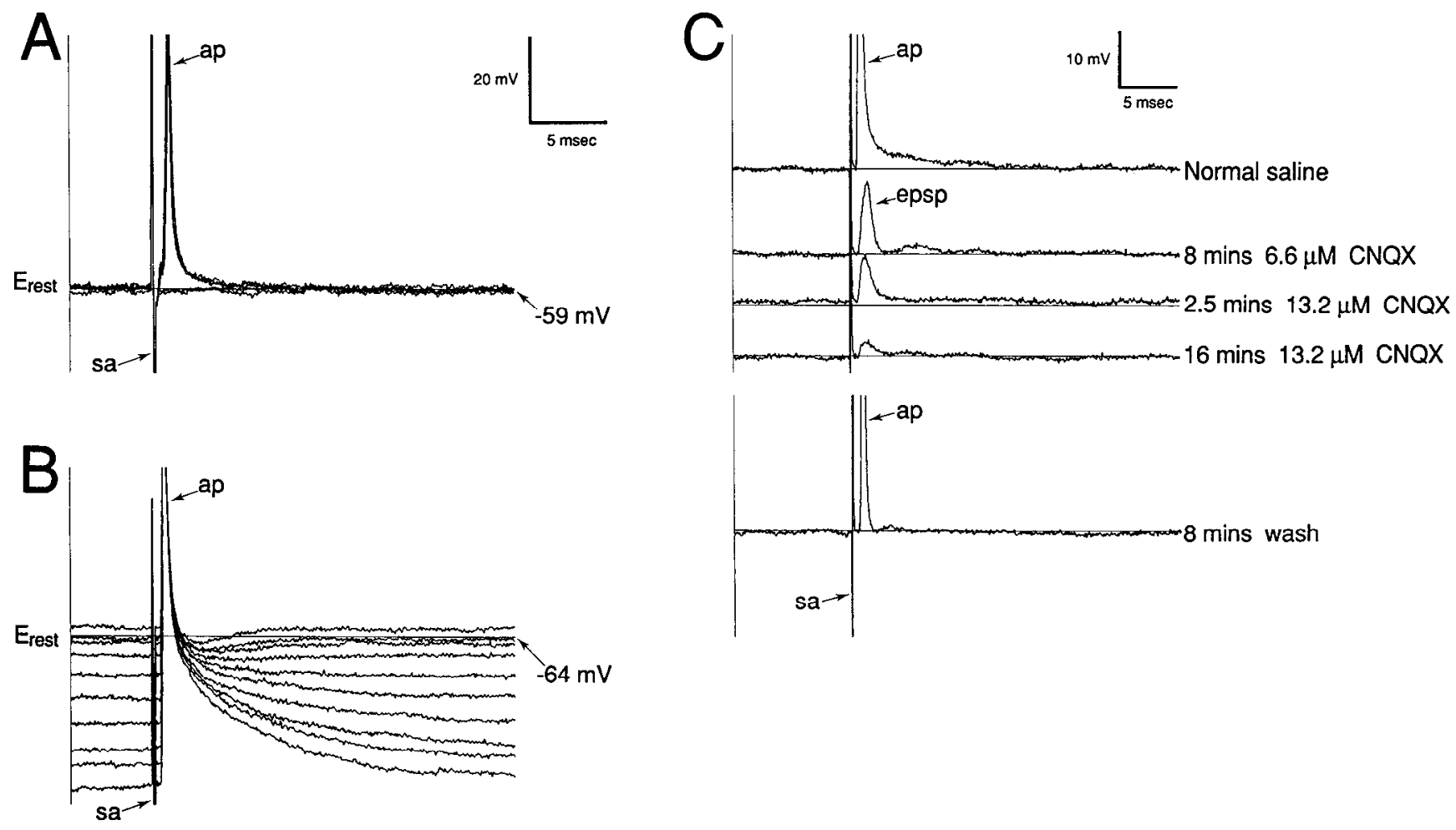

Figure 9. Short-latency responses of MNTB principal cells to midline TB stimulation and the effects of polarization. $A$, Responses of a cell (M21-91 U4) to four shock stimuli of increasing shock strength $(70,80,90$, and $100 \mathrm{~V})$, two subthreshold and two suprathreshold. $B$, Responses of another cell (M7-2-91 U1) to stimuli of identical shock strength while the membrane is polarized to different potentials. $C$, Blockade of the calyceal EPSP by CNQX. Top trace, Suprathreshold response of a principal cell (M4-3-91 U1) to midline stimulation in normal saline. Middle three traces, Responses of the same cell to midline stimuli of identical shock strength as in top trace, showing a gradual blockade of the formerly suprathreshold calyceal EPSP by CNQX. After $11 \mathrm{~min}$ in $6.6 \mu \mathrm{M}$ CNQX, the concentration was doubled. Bottom trace, Response to identical stimulus after return to normal saline for $8 \mathrm{~min} . E_{\text {rest }}=-72 \mathrm{mV}$. $a p$, action potential; $s a$, shock artifact. Calibration in $A$ applies to $B$ as well.

of our cell population, it is likely that we have observed the major projection targets of this cell type within the SOC.

Gross labeling studies have shown that the major projection targets of MNTB cells are ipsilateral LSO (Elverland, 1978; Glendenning et al., 1985; Spangler et al., 1985), as well as the nuclei of the lateral lemniscus and the dorsomedial and ventromedial periolivary nuclei (DMPO, VMPO; Glendenning et al., 1981; Spangler et al., 1985). The axonal projections of single cells in the rat MNTB have not been described in detail previously. Smith et al. (1989) reported that the projections of a small number of individual MNTB principal cells injected in the cat included the ventral nucleus of the lateral lemniscus, LSO, DMPO, VMPO, and occasionally MSO. Using an in vitro brain slice preparation, Zook and colleagues labeled single MNTB principal cclls in the mouse, gerbil, and two species of bats and traced these cells' axonal projections to nuclei within the SOC (Zook and DiCaprio, 1988; Kuwabara and Zook, 1991). These reports showed that the projection within LSO formed rostrocaudal sheets, highly restricted along the tonotopic axis, a pattern of termination similar to that which we observed. Other target nuclei commonly observed within the SOC were SPN, DMPO, VMPO, and ventral nucleus of the trapezoid body (VNTB). About $50 \%$ of the labeled cells projected to MSO, and in $<10 \%$ of these labeled cells, collaterals were observed within MNTB itself. Little interspecies variability was reported. Thus, MNTB cells in the rat appear to have more restricted targets than in other species studied.

The projection to MSO reported here and in other recent studies (Smith et al., 1989; Adams and Mugnaini, 1990; Kuwabara and Zook, 1991) could play a crucial role in the processing of binaural phenomena in MSO. For example, inhibitory inputs have been postulated to sharpen ITD sensitivity in MSO cells by shutting these cells off at unfavorable delays (Yin and Chan, 1990).

This is the first detailed report of a topographic projection from MNTB to SPN (but see Bledsoe et al., 1988), although it should be noted that the tonotopic organization of SPN has not yet been described. The role of SPN in rodents is unclear, but the density of the projections we observed indicates that these cells are strongly suppressed by contralateral CN. Cells in SPN receive input primarily from contralateral $\mathrm{CN}$, and to a lesser extent from ipsilateral CN (Friauf and Ostwald, 1988; Kuwabara et al., 1991). Cells in SPN project to the inferior colliculus (IC; Beyerl, 1978; Faye-Lund, 1986; Schofield, 1991), and this is presumably their major projection target in the rat, since olivocochlear neurons are not present in rat SPN (White and Warr, 1983; Osen et al., 1984), as they are in guinea pig (Schofield, 1991; Thompson and Thompson, 1991). These studies do not address questions concerning the inputs to individual cells or any correlation that may exist between these input patterns and these cells' projection targets. For example, one possibility is that cells receiving ipsilateral excitatory input from the $\mathrm{CN}$ also receive inhibitory input from ipsilateral MNTB, and project to the IC, performing a role similar to LSO principal cells, while cells receiving input from contralateral $\mathrm{CN}$ may have other projection targets. 

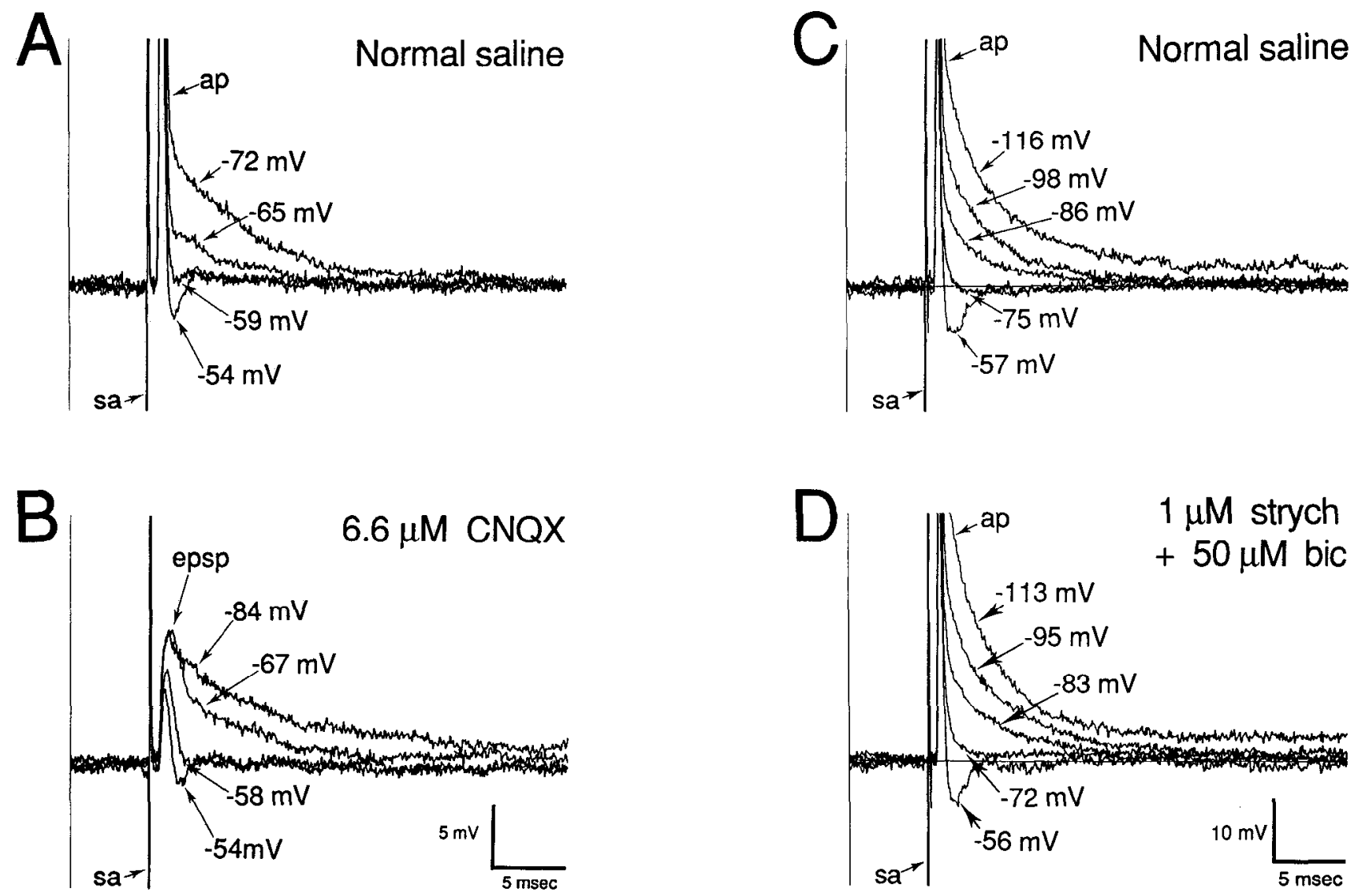

Figure 10. Dependence of the duration of the calyceal event on membrane potential. $A$, Response of the same cell as in Figure $9 C$, in normal saline, to suprathreshold stimuli of identical shock strength with the membrane polarized to different levels (i.e., same paradigm as in Fig. $9 B$ ). Here, the traces are vertically aligned just prior to the shock stimuli. Holding potentials are indicated for each trace. $B$, Same cell and stimulus paradigm as in $A$, but in the presence of $6.6 \mu \mathrm{M}$ CNQX, where the calyceal EPSP is now subthreshold. $C$, Response of another cell (M10-15-91 $\mathrm{U} 2$ ) to the same stimulus paradigm as in $A$ and $B$, in normal saline. $D$, Response of the cell in $C$ to the identical stimulus, but in the presence of $1 \mu \mathrm{M}$ strychnine and $50 \mu \mathrm{M}$ bicuculline, to block glycine and $\mathrm{GABA}_{\mathrm{A}}$ inhibitory events. $E_{\text {rest }}=-72 \mathrm{mV}$ for $A$ and $B$, and $-69 \mathrm{mV}$ for $C$ and $D$. $a p$, action potential; sa, stimulus artifact. Calibration in $B$ applies to $A$ as well; calibration in $D$ applies to $C$ as well.

Non-principal cells. The two non-principal cells included in this report have morphological features similar to elongate cells. These two cells were clearly bipolar but, unlike elongate neurons in the cat (Morest, 1968), have very few spines. The cells we have injected did not send heavy projections to LSO or SPN, and their axons were cut off at the lateral border of the SOC. Since there are apparently no olivocochlear neurons in the rat MNTB (White and Warr, 1983; Osen et al., 1984), they may project to the nuclei of the lateral lemniscus and the IC.

\section{Physiology}

The physiology of MNTB principal cells is similar to that of CN bushy cells (Oertel, 1983; Wu and Oertel, 1984; Manis and Marx, 1991), which give rise to the dominant excitatory inputs to MNTB principal cells (Friauf and Ostwald, 1988). A recent in vitro study by Wu and Kelly (1991) was the first detailed description of intracellular recordings from cells in mouse MNTB. This study was based on recordings from 18 cells that were visually localized to MNTB during the experiment. $I-V$ data were obtained for seven cells, and all showed rectification in their $l-V$ relationships. The responses to current injection in our cell population are similar to those of Wu and Kelly (1991), except that we rarely saw multiple spikes to depolarizing current, and the average steady-state input resistance for hyperpolarizing current in our population was somewhat higher (44.34 \pm 16.84 $\mathrm{M} \Omega ; n=34$, vs. $25.71 \pm 10.36 \mathrm{M} \Omega ; n=5$ ). The former difference may be due to a stronger 4-AP-sensitive conductance in our population, while the latter may be due to differences in morphology or degree of penetration damage, or perhaps due to sampling bias in either study.

Synaptic inputs. In contrast to the slight differences in responses to current injection, there are significant differences between the two studies in synaptic responses to TB stimulation: Wu and Kelly (1991) reported only short-latency, presumably calyceal EPSPs, while in our study we regularly saw long-latency, presumably polysynaptic EPSPs and occasionally short- or longlatency IPSPs. The latter observations are more consistent with reports of significant non-calyceal innervation of MNTB cells (Lenn and Reese, 1966; Jean-Baptiste and Morest, 1975; Casey and Feldman, 1985; Smith et al., 1989; Adams and Mugnaini, 1990; Kuwabara et al., 1991). It should be noted that in those cells in our study where midline stimulation failed to elicit a calyceal event, it is quite possible that either the calyceal axon had been cut off close to the calyx, or that our stimulating electrode was not optimally positioned.

The dependence of the duration of the calyceal event on membrane potential has important implications for the information processing capabilities of MNTB cells. We have shown evidence 

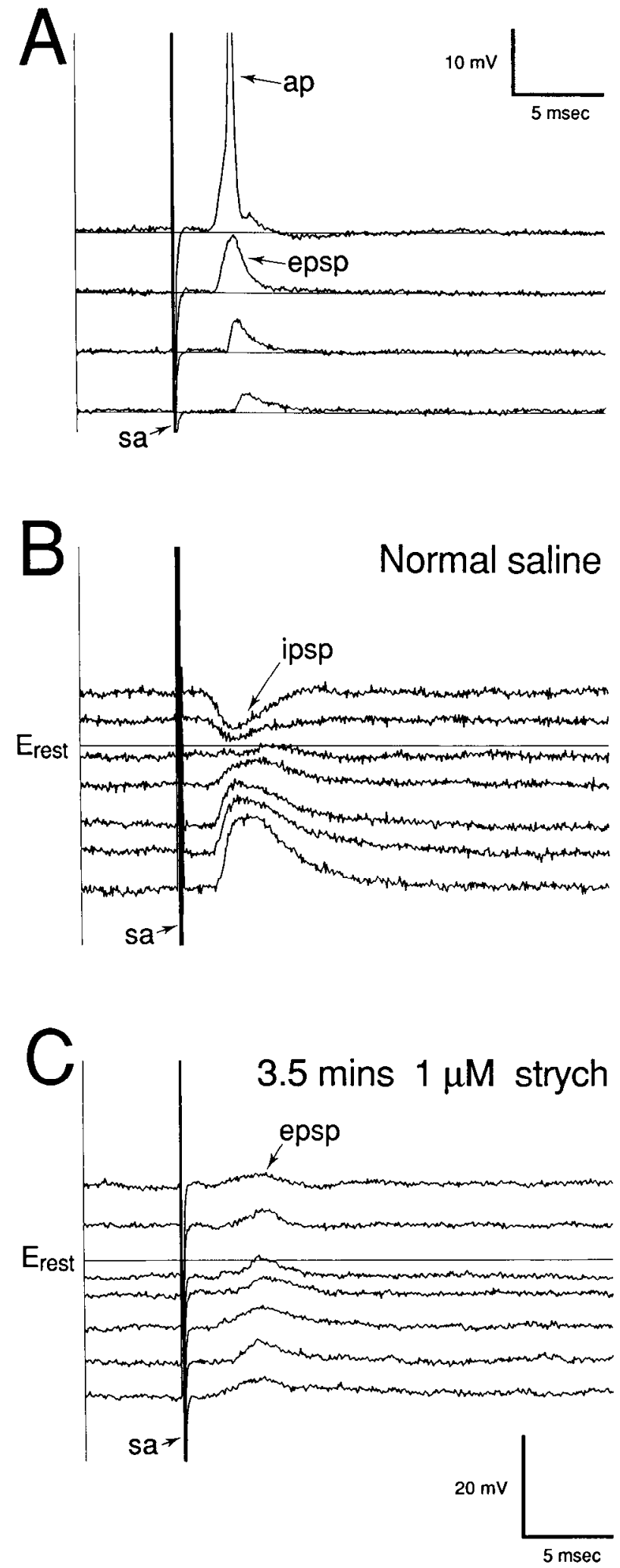

Figure 11. Non-calyceal synaptic events in response to midline TB stimulation. $A$, Response of a principal cell (M5-21-91 U1) to shock stimuli of increasing strength (bottom to top traces). $B$, Responses of another principal cell (M7-26-91 U1) to stimuli of identical shock strength, with the membrane polarized to different levels around rest in order to show the reversal of the IPSP. $C$, Same cell and stimulus paradigm as in $B$, in the presence of $1 \mu \mathrm{M}$ strychnine. ap, action potential $s a$, stimulus artifact. $E_{\text {rest }}=-56 \mathrm{mV}$ for $A$, and $-64 \mathrm{mV}$ for $B$ and $C$. Calibration in $C$ applies to $B$ as well. that this voltage dependence is not due to a late IPSP that reverses near rest, and we postulate that a voltage-dependent conductance, perhaps the 4-AP-sensitive conductance, is responsible for this phenomenon. Application of antagonists for the glycine and $\mathrm{GABA}_{\mathrm{A}}$ receptors in concentrations known to be effective in other systems (Choi and Fischbach, 1981; Wu and Oertel, 1986) had no effect on the voltage dependence of the calyceal event (Fig. 10C,D). Indirect evidence also supports the voltage dependence of the synaptic potential decay being due to intrinsic membrane properties: this phenomenon occurs for both calyceal and non-calyceal EPSPs (not shown), and it is unlikely that all excitatory inputs to these cells, regardless of their origin, are terminated by IPSPs.

The specializations that have developed in this pathway (GBCs and MNTB principal cells), for example, the conductances responsible for these cells' unusual membrane properties and the calyces of Held that form their synaptic connection, support the hypothesis that the primary function of these two cell populations is to relay information quickly and precisely from the periphery to regions of the SOC processing binaural information. Paradoxically, the membrane specializations that have evolved make these cells especially sensitive to small changes in their membrane potential, as would be provided by noncalyceal inputs.

The sources of these non-calyceal inputs is not clear, although at least some are obviously located within the SOC. It is impossible to say whether stimulation of the TB at the midline is orthodromically activating axons crossing from nuclei in the contralateral SOC, or antidromically activating axons from cells in the ipsilateral SOC that give off collaterals in MNTB before crossing the midline to innervate other nuclei. Adams and Mugnaini (1990) showed that MNTB principal cells are contacted by numerous GABA-immunoreactive terminals, and speculated that these GABAergic inputs to MNTB arise in the "ventral periolivary regions," presumably including VNTB. Few glycineimmunoreactive terminals have been reported in MNTB (Wenthold et al., 1987; Helfert et al., 1989; Adams and Mugnaini, 1990), and only sparse glycine receptor labeling has been reported (Zarbin et al., 1981). It is interesting that IPSPs were blocked by strychnine, a glycine receptor antagonist, in the three cases where it was applied. We have not attempted to block IPSPs with GABA antagonists. It is possible that in the rodent, both glycine and GABA are utilized as inhibitory neurotransmitters in MNTB. Parallel to this, although there is heavy labeling for GABA in the cat CN (Adams and Mugnaini, 1987; Saint Marie et al., 1989), interacellular studies in the mouse CN indicate that IPSPs are blocked predominantly by glycinergic antagonists (Wu and Oertel, 1986). One weak source of glycinergic input to MNTB may be collaterals of MNTB principal cells (Fig. 5; see also Kuwabara and Zook, 1991), which are believed to be glycinergic (Wenthold et al., 1987; Bledsoe et al., 1990). Other possible sources of non-calyceal inputs to the MNTB are cells in the surrounding periolivary nuclei (Kuwabara et al., 1991), and collaterals from cells in the LSO crossing the midline, shown to be present in both the cat (Elverland, 1978) and rat (Banks and Smith, 1990).

Ionic currents in MNTB cells. The experiments with 4-AP imply that one or more 4-AP-sensitive conductances exert a powerful influence on the membrane properties of MNTB principal cells and their responses to depolarizing current. These data are consistent with the existence of a 4-AP-sensitive conductance similar to the $g_{\mathrm{B}}$ conductance described in $\mathrm{CN}$ bushy 
A
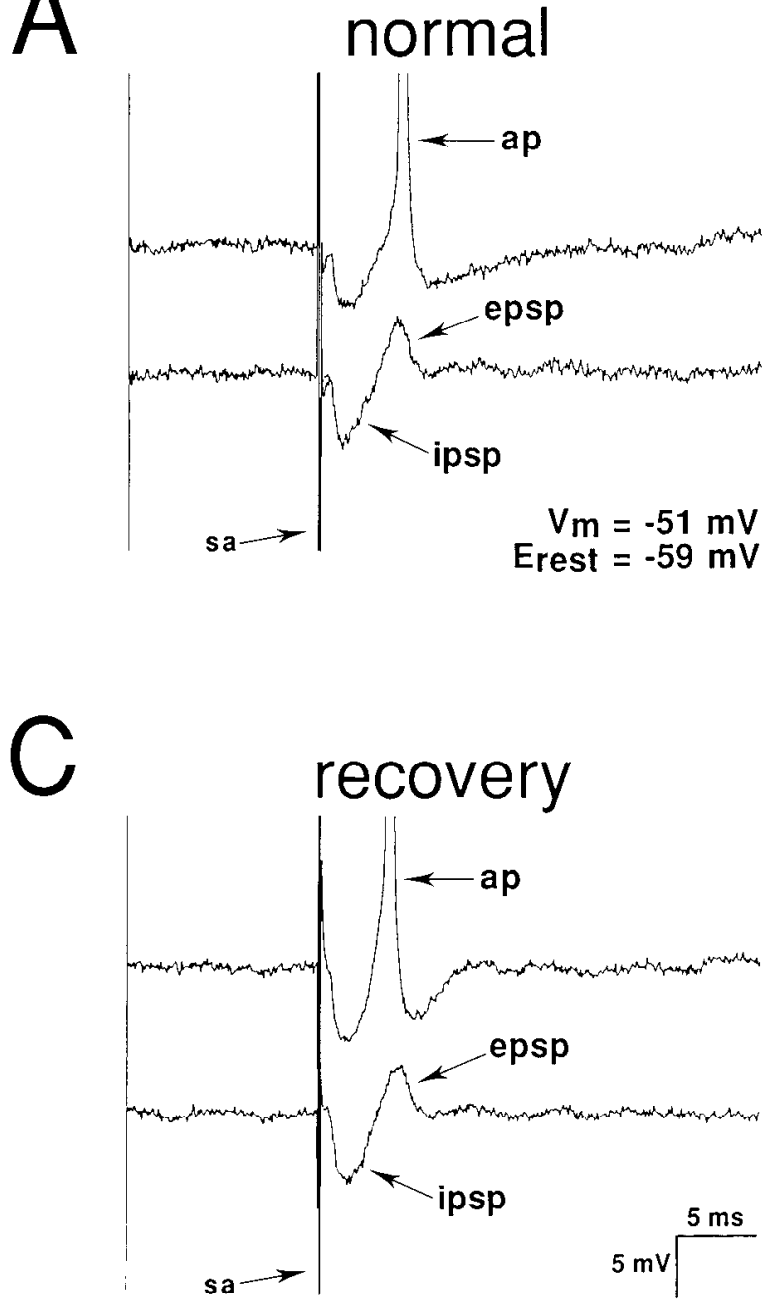

B

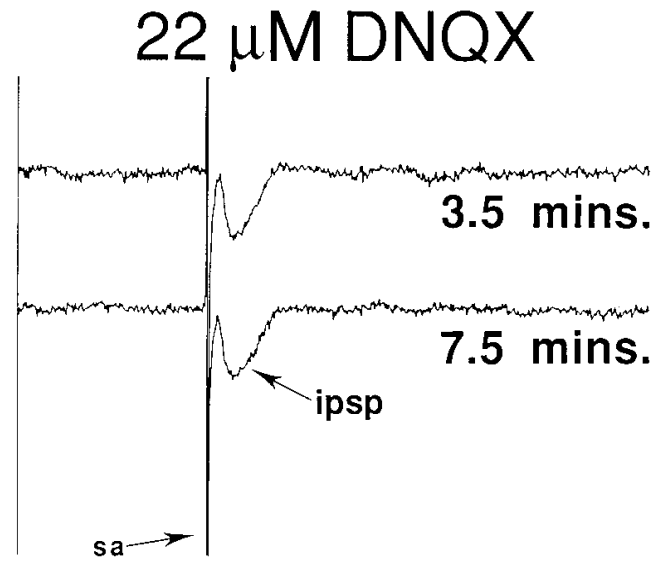

D

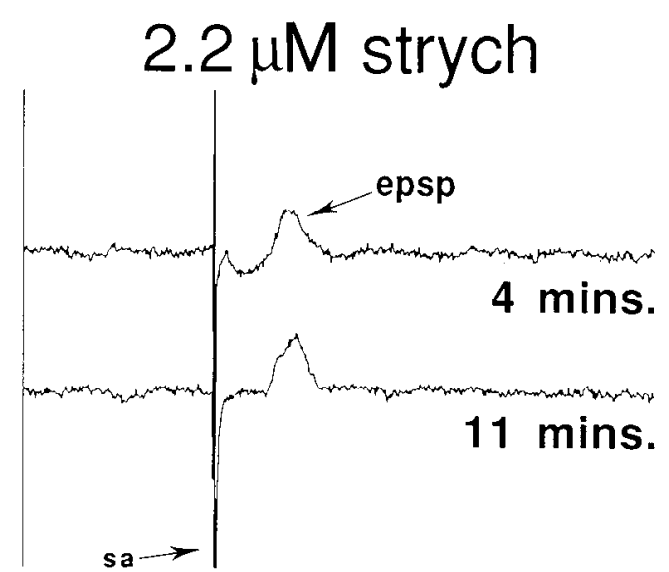

Figure 12. Pharmacology of non-calyceal synaptic events elicited by midline stimulation of the TB. A, Principal cell (M5-21-91 U1) responses in normal saline to subthreshold (bottom trace) and suprathreshold (top trace) shock stimuli. $B$, Response of the same cell to shock stimuli after $3.5 \mathrm{~min}$ (top trace) and $7.5 \mathrm{~min}$ (bottom trace) in $22 \mu \mathrm{M}$ DNQX. $C$. Same paradigm as in $A, 32$ min after returning to normal saline. $D$, Response of the same cell to midline shock stimuli after $4 \mathrm{~min}$ (top trace) and $11 \mathrm{~min}$ (bottom trace) in $2.2 \mu \mathrm{M}$ strychnine. ap, action potential; sa, stimulus artifact. Calibration in $C$ applies to all panels. As indicated in $A$, the cell was slightly depolarized in all panels to accentuate the IPSP.

cells (Manis and Marx, 1991). $g_{\mathrm{B}}$ is a low-threshold, 4-APsensitive potassium conductance that is postulated to be primarily responsible for these cells' transient firing behavior and nonlinear $I-V$ relationships. Without voltage-clamp data, it is impossible to compare the kinetics, reversal potentials, and magnitudes of $g_{\mathrm{B}}$ and the 4-AP-sensitive conductance in MNTB, nor is it possible to rule out the existence of multiple 4-APsensitive conductances in MNTB principal cells. There are, however, obvious similarities between the responses of bushy cells and MNTB principal cells to injected current. Further experiments to determine the functional role of the 4-AP-sensitive conductance are required, for example, examining the dependence of the duration of synaptic potentials, elicited in the presence of 4-AP, on membrane potential. However, a technical difficulty with these experiments is that application of 4-AP significantly changes the synaptic events elicited by TB stimulation, blocking some inputs and revealing others (data not shown).

The sag in membrane potential during a hyperpolarizing current step (Figs. 6, 8) may be due to a hyperpolarization-acti- vated, mixed-cation conductance, similar to the $H$ conductance $\left(g_{\mathrm{H}}\right)$, or anomalous rectifier identified previously in several cell types in the mammalian CNS (Halliwell and Adams, 1982; Crepel and Penit-Soria, 1986; Spain et al., 1987; McCormick and Pape, 1990). The reversal potential for this conductance is typically at or positive to rest, and the time constant of activation is on the order of tens or hundreds of milliseconds. Hyperpolarization of the cell slowly turns on $g_{\mathrm{H}}$, driving the membrane potential back toward the reversal potential for the conductance and causing the sag. The undershoots revealed following depolarizing current steps in the presence of 4-AP (Fig. 8B,E) are consistent with a $g_{\mathrm{H}}$ that is partially active at rest: depolarization deactivates the conductance, and at the stimulus offset the membrane potential undershoots, driven toward the reversal potential for other active conductances.

Thus, MNTB principal cells may have two voltage-dependent conductances responsible for maintaining the cell near its resting potential, the $4-\Lambda \mathrm{P}$-sensitive conductance and the anomalous rectifier. These currents could control modulation by non-calyceal excitatory and inhibitory inputs, and reset the cell subse- 


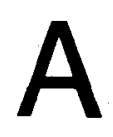

Figure 13. Camera lucida drawings of two non-principal cells in the right MNTB. $A$, A non-principal cell (M620-91 U1) with its cell body within the MNTB. The distal dendritic tree extends dorsoventrally into the areas surrounding the MNTB proper. The axon heads dorsally, through the SPN, and is cut off dorsal to the LSO. $B$, Camera lucida drawing of a non-principal cell (6-20-91 U3) located just outside the lateral border of the MNTB. The dendritic tree extends preferentially in the dorsoventral directions for a considerable distance. The axon heads laterally through the MSO and branches ventral to the LSO before being cut off lateral to the LSO. Line close to the scale bar represents the ventral border of the brainstem.

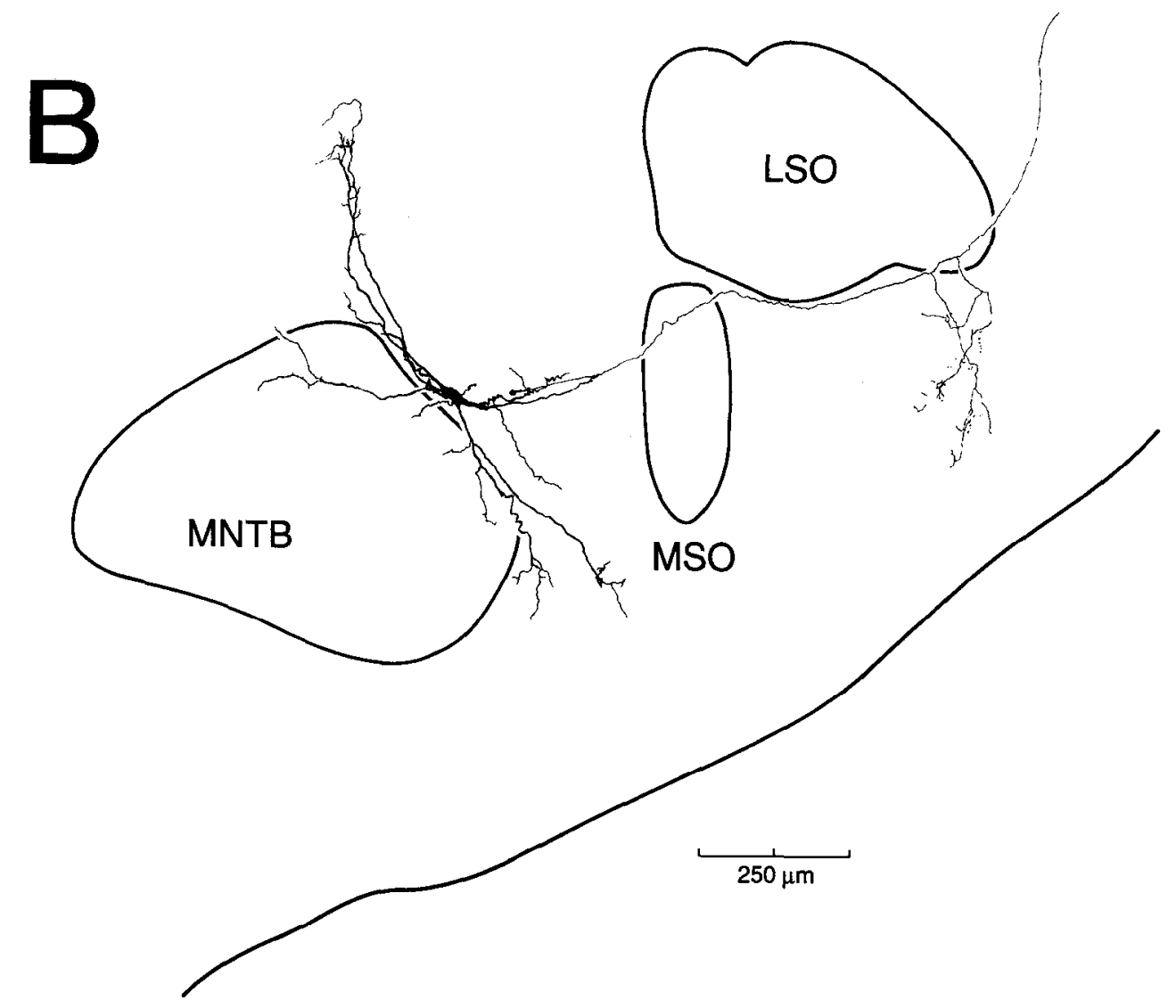



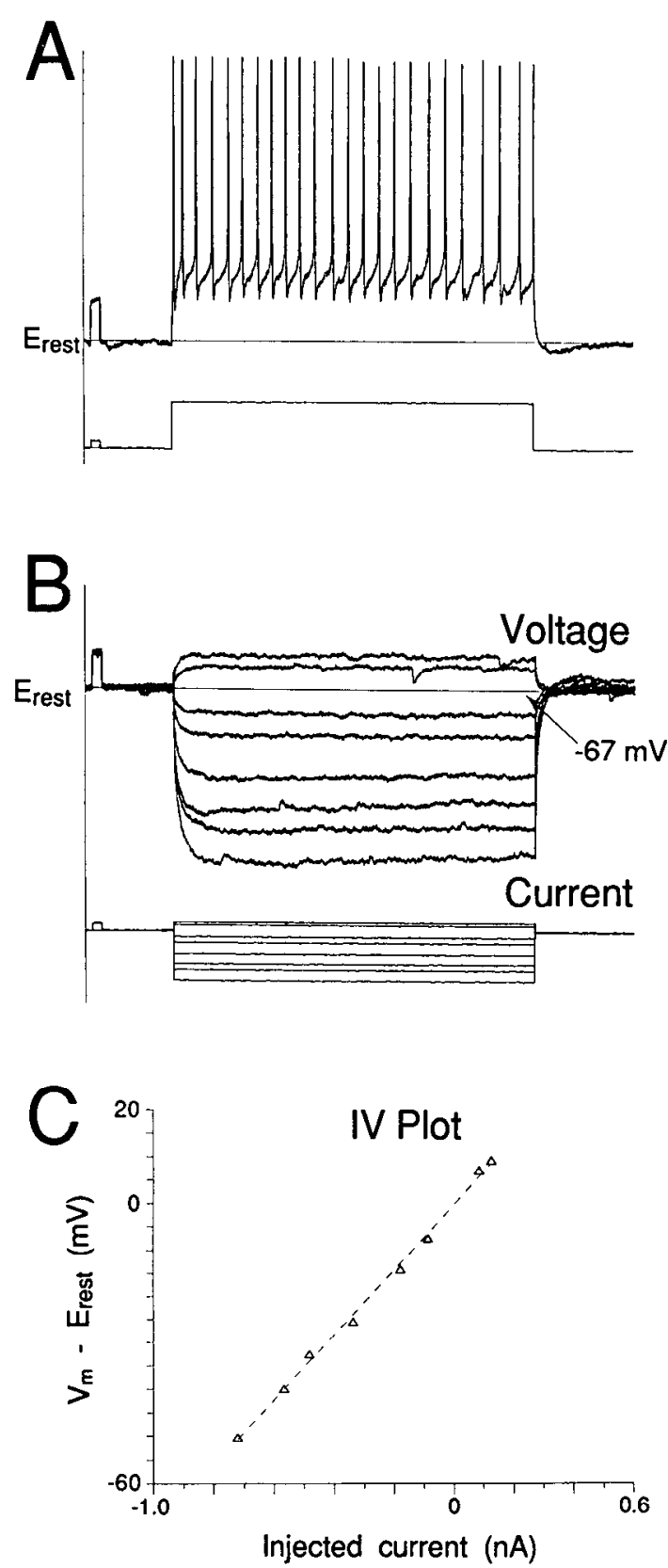
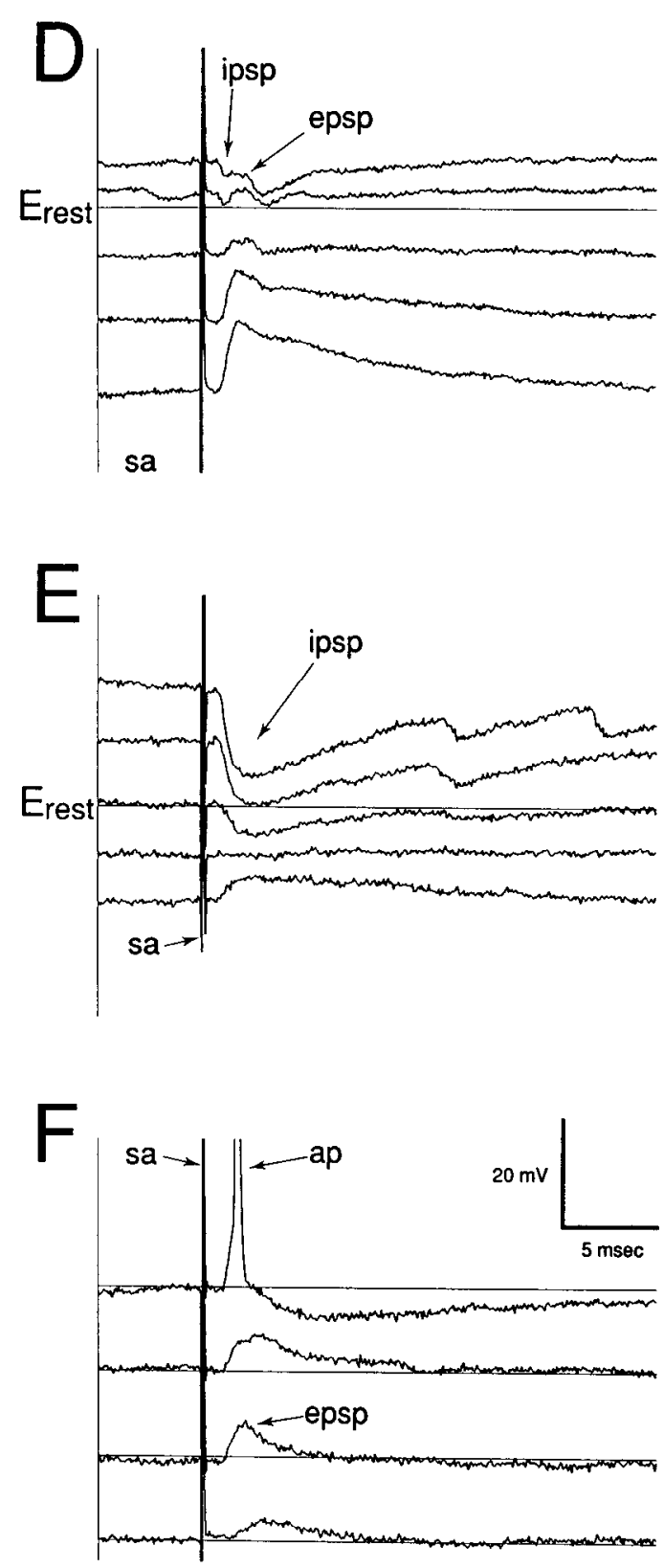

Figure 14. Membrane features and synaptic responses of non-principal cells. $A$, Sustained spiking (top trace) of the cell in Figure $13 A$ to a 200 msec depolarizing current pulse (bottom trace). B. Membrane responses (Voltage) to 200 msec polarizing current pulses (Current). Calibration pulses: voltage, $10 \mathrm{mV}, 5 \mathrm{msec}$; current, $0.1 \mathrm{nA}, 5 \mathrm{msec} . C, I-V$ curve constructed from data in $B$, as described in Materials and Methods, during the steady-state portion of the response. The broken line indicates linear least-squares fit to all data points (slope $=70 \mathrm{M} \Omega$ ). $D$, Synaptic responses of the same cell to midline stimulation. The different traces show the responses to identical shock strengths at varying levels of polarization around rest. $E$, Response of the same cell to stimulation of the ipsilateral TB near the seventh cranial nerve. Paradigm is similar to $D$. $F$, Synaptic response of the cell in Figure $13 B$ to midline stimulation of increasing shock strength (bottom to top traces). ap, action potential; sa, stimulus artifact. Calibration in $F$ applies to $D$ and $E$ as well.

quent to the massive conductance changes elicited by calyceal events.

\section{References}

Adams JC (1981) Heavy metal intensification of DAB-based HRP reaction product. J Histochem Cytochem 29:775.

Adams JC, Mugnaini E (1987) Patterns of glutamate decarboxylase immunostaining in the feline cochlear nuclear complex studied with silver enhancement and electron microscopy. J Comp Neurol 262: $375-401$.
Adams JC, Mugnaini E (1990) Immunocytochemical evidence for inhibitory and disinhibitory circuits in the superior olive. Hearing Res 49:281-298.

Aghajanian GK, Rasmussen K (1989) Intracellular studies in the facial nucleus illustrating a simple new method for obtaining viable motoneurons in adult rat brain slices. Synapse 3:331-338.

Banks MI, Smith PH (1990) Intracellular recordings from cells in the rat superior olivary complex (SOC) labelled with biocytin. Soc Neurosci Abstr 16:722.

Beyerl BD (1978) Afferent projections to the central nucleus of the inferior colliculus in the rat. Brain Res 145:209-223. 
Bledsoe SC Jr, Pandya P, Altschuler RA, Helfert RH (1988) Axonal projections of PHA-L-labeled neurons in the medial nucleus of the trapezoid body. Soc Neurosci Abstr 14:491.

Bledsoe SC Jr, Snead CR, Helfert RH, Prasad V, Wenthold RJ, Altschuler RA (1990) Immunocytochemical and lesion studies support the hypothesis that the projection from the medial nucleus of the trapezoid body to the lateral superior olive is glycinergic. J Comp Neurol 517:189-194.

Boudreau JC, Tsuchitani C (1968) Binaural interaction in the cat superior olive S segment. J Neurophysiol 31:442-454.

Caird D, Klinke R (1983) Processing of binaural stimuli by cat superior olivary complex neurons. Exp Brain Res 52:385-399.

Casey MA, Feldman ML (1982) Aging in the rat medial nucleus of the trapezoid body. I. Light microscopy. Neurobiol Aging 3:187-195.

Casey MA, Feldman ML (1985) Aging in the rat medial nucleus of the trapezoid body. II. Electron microscopy. J Comp Neurol 232: $401-413$

Choi DW, Fischbach GD (1981) GABA conductance of chick spinal cord and dorsal root ganglion neurons in cell cultures. J Neurophysiol 45:605-620.

Crepel F, Penit-Soria J (1986) Inward rectification and low threshold calcium conductance in rat cerebellar Purkinje cells. An in vitro study. J Physiol (Lond) 372:1-23.

Elverland $\mathrm{HH}$ (1978) Ascending and intrinsic projections of the superior olivary complex in the cat. Exp Brain Res 32:117-134.

Faye-Lund H (1986) Projection from the inferior colliculus to the superior olivary complex in the albino rat. Anat Embryol 175:35-52.

Finlayson PG, Caspary DM (1991) Low frequency neurons in the lateral superior olive exhibit phase-sensitive binaural inhibition. J Neurophysiol 65:598-605.

Friauf E, Ostwald J (1988) Divergent projections of physiologically characterized rat ventral cochlear nucleus neurons as shown by intraaxonal injection of horseradish peroxidase. Exp Brain Res 73:263281.

Glendenning KK, Brunso-Bechtold JK, Thompson GC, Masterton RB (1981) Ascending auditory afferents to the nuclei of the lateral lemniscus. J Comp Neurol 197:673-703.

Glendenning KK, Hutson KA, Nudo RJ, Masterton RB (1985) Acoustic chiasm. II. Anatomical basis of binaurality in lateral superior olive of cat. J Comp Neurol 232:261-285.

Guinan JJ, Guinan SS, Norris BE (1972a) Single auditory units in the superior olivary complex I: responses to sounds and classifications based on physiological properties. Int J Neurosci 4:101-120.

Guinan JJ, Norris BE, Guinan SS (1972b) Single auditory units in the superior olivary complex II: locations of unit categories and tonotopic organization. Int J Neurosci 4:147-166.

Halliwell JV, Adams PR (1982) Voltage-clamp analysis of muscarinic excitation in hippocampal neurons. Brain Res 250:71-92.

Held H (1893) Die centrale Gehorleitung. Arch Anat Physiol, Anat Abt 201-248.

Helfert RH, Bonneau JM, Wenthold RJ, Altschuler RA (1989) GABA and glycine immunoreactivity in the guinea pig superior olivary complex. Brain Res 501:269-286.

Honore T, Davies SN, Drejer J, Fletcher EJ, Jacobsen P, Lodge D, Nielsen FE (1988) Quinoxalinediones: potent competitive nonNMDA glutamate receptor antagonists. Science 241:701-703.

Irvine DRF (1986) The auditory brainstem. A review of the structure and function of auditory brainstem processing mechanisms. Prog Sens Physiol 7:1-279.

Jean-Baptiste M, Morest DK (1975) Transneuronal changes of synaptic endings and nuclear chromatin in the trapezoid body following cochlear ablations in cats. J Comp Neurol 162:111-134.

Joris PX, Yin TCT (1990) Time sensitivity of cells in the lateral superior olive (LSO) to monaural and binaural amplitude-modulated complexes. Assoc Res Otolaryngol Abstr 13:267.

Kuwabara N, Zook JM (1991) Classification of the principal cells of the medial nucleus of the trapezoid body. J Comp Neurol 314:707720 .

Kuwabara N, DiCaprio RA, Zook JM (1991) Afferents to the medial nucleus of the trapezoid body and their collateral projections. J Comp Neurol 314:684-706.

Lenn NJ, Reese TS (1966) The fine structure of nerve endings in the nucleus of the trapezoid body and the ventral cochlear nucleus. Am J Anat 118:375-390.
Manis PB, Marx SO (1991) Outward currents in isolated ventral cochlear nucleus neurons. J Neurosci 11:2865-2880.

McCormick DA, Pape HC (1990) Properties of a hyperpolarizationactivated cation current and its role in rhythmic oscillation in thalamic relay neurones. J Physiol (Lond) 431:291-318

Morest DK (1968) The collateral system of the media nucleus of the trapezoid body of the cat, its neuronal architecture and relation to the olivo-cochlear bundle. Brain Res 9:288-311.

Morest DK (1973) Auditory neurons of the brain stem. Adv Otorhinolaryngol 20:337-356.

Nicoll RA, Alger BE (1981) A simple chamber for recording from submcrged brain sliccs. J Ncurosci Mcthods 4:153-156.

Oertel D (1983) Synaptic responses and electrical properties of cells in brain slices of the mouse anteroventral cochlear nucleus. J Neurosci 3:2043-2053.

Ollo C, Schwartz IR (1979) The superior olivary complex in C57BL/6 mice. Am J Anat 155:345-374.

Osen KK, Mugnaini E, Dahl AL, Christiansen AH (1984) Histochemical localization of acetylcholinesterase in the cochlear and superior olivary nuclei. A reappraisal with emphasis on the cochlear granule cell system. Arch Ital Biol 122:169-212.

Paxinos G, Watson C (1986) The rat brain in stereotaxic coordinates. New York: Harcourt Brace Jovanovich.

Saint Marie RL, Morest DK, Brandon CJ (1989) The form and distribution of GABAergic synapses on the principal cell types of the ventral cochlear nucleus of the cat. Ilearing Res 42:97-112.

Schofield BR (1991) Superior paraolivary nucleus in the pigmented guinea pig: separate classes of neurons project to the inferior colliculus and the cochlear nucleus. J Comp Neurol 312:68-76.

Schofield BR, Cant NB (1991) Organization of the superior olivary complex in the guinea pig. I. Cytoarchitecture, cytochrome oxidase histochemistry, and dendritic morphology. J Comp Neurol 314:645670.

Smith PH, Joris PX, Banks MI, Yin TCT (1989) Physiology and anatomy of principal cells in the cat MNTB. Soc Neurosci Abstr 15: 746.

Smith PH, Joris PX, Carney LH, Yin TCT (1991) Projections of physiologically characterized globular bushy cell axons from the cochlear nucleus of the cat. J Comp Neurol 304:387-407.

Spain WJ, Schwindt PC, Crill WE (1987) Anomalous rectification in neurons from cat sensorimotor cortex in vitro. J Neurophysiol 57: $1555-1576$

Spangler KM, Warr WB, Henkel CK (1985) The projections of principal cells of the medial nucleus of the trapezoid body in the cat. $J$ Comp Neurol 238:249-262.

Spirou GA, Brownell WE, Zidanic M (1990) Recordings from cat trapezoid body and HRP labeling of globular bushy cell axons. J Neurophysiol 63:1160-1190.

Thompson AM, Thompson GC (1991) Posteroventral cochlear nucleus projections to olivocochlear neurons. J Comp Neurol 303:267285.

Tolbert LP, Morest DK, Yurgelun-Todd DA (1982) The neuronal architecture of the anteroventral cochlear nucleus of the cat in the region of the cochlear nerve root: horseradish peroxidase labelling of identified cell types. Neuroscience 7:3031-3052.

Tsuchitani C, Boudreau JC (1966) Single unit analysis of cat superior olive S-segment with tonal stimuli. J Neurophysiol 29:684-697.

Warr WB (1972) Fiber degeneration following lesions in the multipolar and globular cell areas in the ventral cochlear nucleus of the cat. Brain Res 40:247-270.

Wenthold RJ, Huie D, Altschuler RA, Reeks KA (1987) Glycine immunoreactivity localized in the cochlear nucleus and superior olivary complex. Neuroscience 22:897-912.

White JS, Warr WB (1983) The dual origins of the olivocochlear bundle in the albino rat. J Comp Neurol 219:203-214.

Wu SH, Kelly JB (1991) Physiological properties of neurons in the mouse superior olive: membrane characteristics and postsynaptic responses studied in vitro. J Neurophysiol 65:230-246.

Wu SH, Oertel D (1984) Intracellular injection with horseradish peroxidase of physiologically characterized stellate and bushy cells in slices of mouse anteroventral cochlear nucleus. J Neurosci 4:15771588 .

Wu SH, Oertel D (1986) Inhibitory circuitry in the ventral cochlear nucleus is probably mediated by glycine. J Neurosci 6:2691-2706. 
Yin TCT, Chan JCK (1990) Interaural time sensitivity in medial superior olive of cat. J Neurophysiol 64:465-488.

Yin TCT, Kuwada S (1984) Neuronal mechanisms of binaural interaction. In: Dynamical aspects of neocortical function (Edelman GM, Gall WE, Cowan WM, eds), pp 263-313. New York: Wiley.
Zarbin MA, Walmsley JK, Kuhar MJ (1981) Glycine receptor: light microscopic autoradiographic localization with $\left[{ }^{3} \mathrm{H}\right]$ strychnine. J Neurosci 1:532-547.

Zook JM, DiCaprio RA (1988) Intracellular labelling of afferents to the lateral superior olive. Hearing Res 34:141-148. 